\title{
Tabularia
}

Sources écrites des mondes normands médiévaux

\section{Five charters concerning the early history of the chapter at Avranches}

Cinq chartes au sujet de l'histoire des débuts du chapitre à Avranches

\section{Richard Allen}

\section{OpenEdition}

\section{Journals}

Electronic version

URL: http://journals.openedition.org/tabularia/2516

DOI: $10.4000 /$ tabularia. 2516

ISSN: $1630-7364$

\section{Publisher:}

CRAHAM - Centre Michel de Boüard, Presses universitaires de Caen

\section{Electronic reference}

Richard Allen, «Five charters concerning the early history of the chapter at Avranches », Tabularia [Online], Sources en ligne, Online since 10 March 2008, connection on 20 April 2019. URL : http:// journals.openedition.org/tabularia/2516; DOI : 10.4000/tabularia.2516 


\title{
Five charters concerning the early history of the chapter at Avranches ${ }^{1}$
}

\section{Cinq chartes au sujet de l'histoire des débuts du chapitre à Avranches}

\author{
Richard ALLEN \\ University of Glasgow \\ rallen200@yahoo.com
}

\begin{abstract}
:
The cartulary of Avranches cathedral, known as the Livre vert, contains five important charters concerning the deanship of Avranches. Known to nineteenth-century antiquarians, but overlooked by modern scholarship, the charters have never been studied despite their significance for the early history of the Avranches chapter. The following article not only discusses the creation of the deanship, an event that saw the completion of a process of renewal that had begun in the diocese at the end of the tenth-century, but also provides critical editions of all five acts. These include hitherto unpublished charters of Hugh of Amiens, archbishop of Rouen.
\end{abstract}

Keywords: Turgis, bishop of Avranches, Richard de Subligny, bishop of Avranches, Hugh of Amiens, archbishop of Rouen, deanship, cathedral chapter, Vains, cartulary, charter.

Résumé:

Le cartulaire de la cathédrale d'Avranches, connu sous le nom de Livre vert, contient cinq chartes importantes au sujet du doyenné d'Avranches. Bien connu par des érudits $d u$ XIXe siècle, ces chartes n'ont pas été étudiées par les spécialistes modernes, en dépit de leur importance pour l'histoire des débuts du chapitre d'Avranches. L'article suivant discute non seulement la création du doyen, un événement qui a vu l'accomplissement d'un processus de renouvellement qui avait commencé dans le diocèse à la fin $d u X^{e}$ siècle, mais fournit également les éditions critiques des cinq actes. Ceux-ci comprennent des chartes jusqu'à maintenant non publiées de Hugues d'Amiens, archevêque de Rouen.

Mots-clés: Turgis, évêque d'Avranches, Richard de Subligny, évêque d'Avranches, Hugues d'Amiens, archevêque de Rouen, doyen, chapitre, Vains, cartulaire, charte.

1. Thanks must go to M. Jean-Luc Leservoisier, conservateur of the fonds ancien of Avranches, who made my recent stay in the city so enjoyable, and who was kind enough to provide wonderful colour digital images of the relevant folia. The author is also indebted to Pierre Bauduin, Véronique Gazeau and Stephen Marritt for comments on earlier drafts of this article. Any errors that remain are, of course, my own. 
Any assessment of the history of the episcopal see of Avranches, the smallest and one of the most westerly dioceses in the ecclesiastical province of Rouen, is plagued by an overwhelming paucity of sources. This is a consequence of both medieval and modern circumstances. Like most parts of northern France, the Avranchin suffered heavily following the Northmen incursions of the ninth century $^{2}$. The region was also ravaged by Breton attacks at this time ${ }^{3}$, a problem that would continue to plague the area well into the eleventh century ${ }^{4}$, and, as a result, the bishopric was, like the neighbouring diocese of Coutances, effectively severed from the ecclesiastical chain of command ${ }^{5}$. The cathedral was abandoned, churches razed to the ground, relics scattered, and the destruction in the region so profound that the seat lay vacant for over a century ${ }^{6}$. Although the bishopric was reoccupied during the last years of the reign of Richard I (942996), we know very little of the prelates who came to regenerate the diocese during the first half of the eleventh century ${ }^{7}$. At the beginning of the nineteenth century the city suffered another blow when the remaining ruins of the cathedral, which had fallen into disuse during the preceding decades, collapsed and were removed. It is possible to substitute this great loss through various drawings

2. The Northmen first appeared in the region in 841; Nithard, Histoire des fils de Louis de Pieux, éd. Philippe Lauer, Paris, Les Belles Lettres, 1926, p. 56; Annales fontanellenses priores, éd. Jean LAPORTE, Mélanges de la Société de l'Histoire de Normandie, 15, 1951, p. 74-75.

3. Charles the Bald granted the Avranchin and Cotentin to Solomon, king of Brittany, following the peace negotiated at Compiègnes in 867; Chédeville, André and guillotel, Hubert, La Bretagne des saints et des rois: $V^{e}-X^{e}$ siècle, Rennes, Ouest-France, 1984, p. 317-318, 327; SMITH, Julia, Province and empire: Brittany and the Carolingians, Cambridge, Cambridge University Press, 1992, p. 87. Although the region would eventually return to Norman control, the Breton influence in the region was long lasting, a fact illustrated by one of the families under discussion here. For further examples, see Keats-Rohan, Katherine S.B., "William I and the Breton contingent in the non-Norman Conquest 1060-1087", Anglo-Norman Studies, 13, 1990, p. 157-172; ID, "The Bretons and Normans of England 1066-1154: the family, the fief and the feudal monarchy", Nottingham Medieval Studies, 36, 1992, p. 42-78.

4. In 1061, the monks of Mont-Saint-Michel claimed that they were being repeatedly called to Avranches, despite the risk from the rising tide or Breton ambushes; "Cogebantur enim uenire Abrincas..., nec excusare poterat eos mare insurgens, nec Britonum insidie..."; KeATs-Rohan, Katherine S.B. (ed.), The cartulary of the abbey of Mont-Saint-Michel, Donington, Shaun Tyas, 2006, Appendix II, $\mathrm{n}^{\circ} 5$.

5. For the reconstruction of the diocese of Coutances following the disruption of the ninth and tenth centuries, see FonTANEL, Julie, "La réorganisation religieuse sous Guillaume le Conquérant: le cas de l'église de Coutances", Revue de l'Avranchin et du Pays de Granville, 77, 2000, p. 189-208. For a reassessment of the Cotentin's early history as part of ducal Normandy, see VAN ToRHoudT, Eric, "Les sièges du pouvoir des Néel, vicomtes dans le Cotentin", in Les lieux de pouvoir au Moyen Âge en Normandie et sur ses marges, Anne-Marie Flambard Héricher (dir.), Caen, Publications du CRAHM, 2006, p. 7-35.

6. Gallia Christiana in provincias ecclesiasticas distributa, 16 vol., Paris, Victor Palme, 1715-1865, XI, col. 474 (hereafter Gallia Christiana).

7. Bouet, Pierre et Dosdat, Monique, "Les évêques normands de 985 à 1150", in Les évêques normands du XI e siècle, Pierre Bouet et François Neveux (dir.), Caen, Presses universitaires de Caen, 1996, p. 19-37, at p. 22-24. A comprehensive analysis of the tenth- and eleventh-century episcopate is currently in preparation by the author; ALLEN, Richard, "The Norman episcopate and the emergence of the Norman state, 989-1110”, doctoral thesis, University of Glasgow, in preparation. 
and plans of the cathedral ${ }^{8}$, as well as the findings of excavations carried out in the 1970 , but the architectural history of the cathedral remains woefully incomplete $^{9}$. Fortunately, the cathedral's patrimony survived the greatest disaster to befall the region, since it was not conserved at the departmental archives of la Manche (Saint-Lô), which were almost completely destroyed on 6 June $1944^{10}$. Consequently, we are in possession of a cartulary for the cathedral, whose contents will form the basis of this article ${ }^{11}$. The consequences of the calamities to befall the diocese means, however, that no original document issued by the bishops of Avranches survives from either the eleventh or twelfth centuries ${ }^{12}$.

\section{The bishops of Avranches, c. 990-1134}

The first bishop to reoccupy the see after the vacancy of the eighth and ninth centuries was Norgod (c. 990 -c. 1017) ${ }^{13}$. Although he was responsible for the revival of the diocese, he was clearly overwhelmed by the destruction with which he was confronted, since he removed himself from his duties to become a monk at the nearby abbey of Mont-Saint-Michel in around $1017^{14}$. His successor, Maugis (c. 1022 -c. 1026), was also gripped by the desire to retreat to the monastery, and was only prevented from doing so by its abbot ${ }^{15}$. The next bishop, Hugh (c. 1028 -c. 1060), occupied the see for over thirty years, but he seems to have focused his attentions on Upper Normandy, where he was particularly involved with the abbey of Fécamp ${ }^{16}$. A reliable but late source, the Vita Lanfranci, suggests that Lanfranc visited Avranches during Hugh's episcopate ${ }^{17}$, but while

8. For details of these drawings and plans, see PIGEON, Émile-Auber, Le diocèse d'Avranches, sa topographie, ses origines, ses évêques, sa cathédrale, ses églises, ses comtes et ses châteaux, 2 vol., Coutances, Salettes, 1888, I, p. 7.

9. Levalet, Daniel, "La cathédrale Saint-André et les origines chrétiennes d'Avranches”, Archéologie médiévale, 12, 1982, p. 107-153, esp. p. 121-123.

10. For details, see "Répertoire des bibliothèques et archives de la Manche", Revue de la Manche, 4 (1962), p. 357-441, esp. p. 402-403, 410. Cf. the database CartulR: http://www.cn-telma.fr/cartulR.

11. Bibl. mun. Avranches, ms 206.

12. When Henri Omont produced his catalogue of manuscripts in French municipal libraries, there was a charter issued by a twelfth-century bishop of Avranches in the municipal library at Falaise (Bibl. mun. de Falaise, ms 28, pièce 1), but this was destroyed during World War II. I am grateful to Mme Elisabeth Delahaye, conservateur of the Médiathèque du Pays de Falaise, for informing me of this loss.

13. Fauroux, Marie (éd.), Recueil des actes des ducs de Normandie, 911-1066, Mémoires de la Société des antiquaires de Normandie, 36, 1961, $\mathrm{n}^{\circ} 4$ (hereafter Fauroux, Recueil...).

14. Norgod's final appearance in the diplomatic record dates from this year; Mabillon, Jean (éd.), Annales ordinis Sancti Benedicti occidenalium monachorum patriarchae, 6 vols., Luca, Leonardi Venturini, 1739-1745, IV, p. 253-254.

15. Desroches, Jean-Jacques, “Annales religieuses de l'Avranchin”, 3 parts, Mémoires de la Société des antiquaires de Normandie, 14, Rouen, 1844, p. 395-489; 17, Rouen, 1850, p. 11-90, 321-387, I, p. 418.

16. Fauroux, Recueil..., $\mathrm{n}^{\circ} 72,93,145$. These charters are discussed in Bates, David, Normandy before 1066, London, Longman, 1982, p. 158-159.

17. Gibson, Margaret (ed.), Vita Lanfranci, in Lanfranco di Pavia e l'Europa del secolo XI nel IX centenario della morte (1089-1989), Giulio D'OnofRio (éd.), Rome, Herder, 1993, p. 659-715, at p. 668. 
early scholars understood this to indicate the presence of a cathedral school in the city ${ }^{18}$, most modern authorities are more sceptical ${ }^{19}$. His successor, John (c. 1060-1067) ${ }^{20}$, came from one of the most influential families in the duchy ${ }^{21}$, and while his episcopate marked the beginning of the reintegration of the diocese into the Norman ecclesiastical mainstream, two important institutions, the chapter and the cathedral itself, remained only half restored ${ }^{22}$. Indeed, the degree to which the chapter was starved of personnel is illustrated by the famous conventio drawn up between John and the abbot of Mont-Saint-Michel in 1061, in which the bishop made the abbot his archdeacon ${ }^{23}$. The situation would improve considerably during the tenure of the next bishop, Michael (1068-1094), a former royal chaplain, for under his rule we can name two archdeacons (Peter and Gilbert), a scholasticus (John), and five canons (Bernard, Ernesy of Verdun, Garner, Gauslin and Serlo). The bishop obviously did not struggle to find men of a high quality, for one of them (the canon Serlo) would later become abbot of St. Peter's, Gloucester ${ }^{24}$. The final years of Michael's episcopate were dominated by the transition of power in Normandy between William II (1035-1087) and his son Robert Curthose (1087-1106). Following the failed rebellion of Odo, bishop of Bayeux (c. 1049-1097) and Robert, count of Mortain (c. 1055-1095), in England in March 1088, the duke, in a desperate bid to raise funds, granted the Cotentin and the Avranchin, including the bishopric of Avranches, to his brother Henry, in return for three thousand livres ${ }^{25}$. The move had dramatic consequences for the region, which was essentially severed from the rest of the duchy.

18. Lebreton, Charles, "L'école d'Avranches au XIe siècle sous Lanfranc et saint Anselme", Mémoires de la Société archéologique d'Avranches, 6, 1873, p. 493-510; MACDonaLD, Allan John, Lanfranc: a study of his life, work and writing, London, Milford, 1926, p. 11.

19. Gibson, Margaret, Lanfranc of Bec, Oxford, Clarendon Press, 1978, p. 20-21; CowDrey, Herbert E.J., Lanfranc: scholar, monk, archbishop, Oxford, Oxford University Press, 2003, p. 10.

20. AlLeN, Richard, "'A proud and headstrong man': John of Ivry, bishop of Avranches and archbishop of Rouen, 1067-1079", Historical Research, (forthcoming).

21. He was the son of Rodulf, count of Ivry, the uterine brother of Richard I. For Rodulf s career, see BAuduin, Pierre, La première Normandie ( $X^{e}-X I^{e}$ siècles): sur les frontières de la haute Normandie, Caen, Presses universitaires de Caen, 2004, p. 191-215, esp. p. 197-209.

22. SPEAR, David (ed.), The personnel of the Norman cathedrals during the ducal period, 911-1204, London, Institute of Historical Research (coll. Fasti Ecclesiae Anglicanae. 1066-1300), 2006, p. 3-28; LeVALET, "La cathédrale Saint-André...", p. 121-123.

23. Keats-Rohan, The cartulary..., Appendix II, $\mathrm{n}^{\circ}{ }_{5}$. Of course, this arrangement also sought to limit the abbey's influence in the region; LEMARIGNIER, Jean-François, Étude sur les privilèges d'exemption et de juridiction ecclésiastique des abbayes normandes depuis les origines jusqu'en 1140, Paris, Picard, 1937, p. 158-160.

24. SPeAR, The personnel..., p. 25.

25. The details of this agreement, which are recorded by Orderic (Chibnall, Marjorie (éd.), The Ecclesiastical History of Orderic Vitalis, 6 vol., Oxford, Clarendon Press, 1969-1980, IV, p. 118120) (hereafter $O V$ ), are confirmed by diplomatic evidence. It has been followed by all modern authorities; DAvid, Charles W., Robert Curthose, duke of Normandy, Cambridge (Mass.), Harvard University Press, 1920, p. 48-49; Barlow, Frank, William Rufus, London, Methuen, 1983, p. 69-70; Hollister, C. Warren, Henry I, London, Yale University Press, 2001, p. 49-61. 
Unfortunately, the origins of Michael's successor, Turgis (1094-1134), are as obscure as those of his predecessors ${ }^{26}$. His name, which derives from the Scandinavian Porgisl, was common in Normandy, and endured in the region until the fifteenth century ${ }^{27}$. An anonymous contributor to the Revue de l'Avranchin speculated that the bishop was from the Avranchin, and that he was perhaps a relative of the counts of Avranches, although there is no evidence to justify this ${ }^{28}$. Whether Turgis had any previous ecclesiastical experience before ascending to the see is also unclear. H.W.C. Davis identified a Turgis capellanus who appears in a royal charter issued by William Rufus at Dover on 27 January 1091 as the future bishop of Avranches ${ }^{29}$, while Charles Haskins dated a charter issued by Ivo Taillebois to 1094, because he believed that the Turgis capellanus regis who witnessed this act was the same man ${ }^{30}$. Although the prevalence of the name noted above means such conclusions are slender, the fact that Turgis was both preceded and succeeded in his see by royal chaplains certainly tempts such a connection. Elsewhere, Orderic Vitalis mentions a Turgis who was chanter of Lisieux in 1077, but it seems unlikely that this is our bishop. Not only does the monk of Saint-Évroult fail to identify him as a future bishop, but also Turgis the chanter seems to have died sometime before $1113^{31}$.

The first decade of Turgis' episcopate was dominated by the troubles of the reign of Robert Curthose ${ }^{32}$. His predecessor's acquiescence to Henry's requisition of the Avranchin had effectively severed the bishopric from the rest of the duchy. Elsewhere, the disruption to ecclesiastical affairs throughout Normandy was profound, and contemporary narratives speak of private war, pillage, rapine and the wanton destruction of ecclesiastical property ${ }^{33}$. The diplomatic record verifies the dreary picture painted here. Duke Robert issued no ducal charter for the cathedral of Avranches throughout his entire reign (his name appears

26. For a very short assessment of Turgis' episcopate, see SpEar, David, "The Norman episcopate under Henry I king of England and duke of Normandy (1106-1135)”, PhD Thesis, University of California, Santa Barbara, 1982, p. 35-36 (dactyl.)

27. Adigard des Gautries, Jean, Les noms de personnes scandinaves en Normandie de 911 à 1066, Lund, 1954, p. 159-160, 321-322.

28. L.C., “Turgis, évêque d'Avranches (1094-1134)”, Revue de l'Avranchin et du pays de Granville, 49, 1972, p. 71-73, at p. 71.

29. Davis, Henry W.C. (ed.), Regesta Regum Anglo-Normannorum, 1066-1154 : Regesta Willelmi Conquestoris et Wilhelmi Rufi, Oxford, Clarendon Press, 1913, $\mathrm{n}^{\circ} 315$. For the identification, see the "Index of Persons", p. 152.

30. Haskins, Charles H., Norman institutions, Cambridge, Mass., 1918, p. 74 n. 29. For the charter text, see Métais, Charles (éd.), Cartulaire de l'abbaye cardinale de la Trinité de Vendôme, 5 vol., Paris, 1893-1904, II, n CCCLI.

31. OV, III, p. 20. For discussion, see Spear, “The Norman episcopate...", p. 35; SpEAR, The personnel..., p. 181.

32. The best survey of Curthose's reign remains, DAvid, Charles Wendell, Robert Curthose..., op. cit. n.25, XIV + 271 p. See also, Haskins, Norman institutions, p. 64-84.

33. The fullest account is that of Orderic Vitalis; $O V$, IV, p. 112, 146-148, 226-228; v, p. 26, 300-302; VI, p. 32-36. 
alongside that of the bishop in only one transaction) ${ }^{34}$, and even under the more organised governorship of William Rufus, the cathedral and bishop (with one exception) are conspicuous by their absence from the corpus of extant royal charters ${ }^{35}$. Frank Barlow included Turgis among a group of "courtiers" who accompanied Rufus back to England in 1097 after his successful acquisition of Normandy the year before, yet any such intimacy was apparently short lived, since the bishop is never again found in the presence of the king ${ }^{36}$. While Turgis appears in two charters broadly dated during the opening years of his episcopate ${ }^{37}$, there is no surviving document dated to a single year until after Henry's victory at Tinchebray ${ }^{38}$. Of course, the situation under Henry I improved considerably. While Turgis seems not to have been an intimate of the king, only venturing out of the Avranchin when it was required of him, he was a prelate actively involved in the religious life of both his diocese, and Europe as a whole. He was an active patron of Vitalis the hermit's new foundation at Savigny ${ }^{39}$, a recipient of at least two papal bulls ${ }^{40}$, and even a correspondent of Ivo, bishop of Chartres ${ }^{41}$. He is, it is certain, undeserving of his reputation as "obscure" ${ }^{2}$. The community at Avranches would also benefit greatly during Turgis' episcopate. The bishop began a second phase of building on the cathedral ${ }^{43}$, and on 17 September 1121 he consecrated the new edifice ${ }^{44}$. For the first time since the refoundation of the late tenth century the cathedral chapter also had a full complement of personnel, and the key new position created by Turgis was the deanship. Scholars of the nineteenth century were well acquainted with this fact, the details of which they claimed appeared in the cartulary of the cathedral.

34. For a list of charters issued by Robert between 1087 and 1104, see Haskins, Norman institutions, p. 66-7o. For the sole document that mentions both the duke (his name simply appears as a dating clause) and Turgis, see Routt, Dominique, Le cartulaire de l'abbaye bénédictine de SaintPierre-de-Préaux (1034-1227), Paris, Éditions du CTHS, 2004, nº A 122.

35. For a list of charters issued by William Rufus in Normandy, see Haskins, Norman institutions, p. 8o-81.

36. Barlow, William Rufus, p. 372 .

37. BnF, ms lat. 5441 (II), p. 161-162; Rouet, Cartulaire de Saint-Pierre-de-Préaux, nº A 122.

38. Johnson, Charles and Cronne, Henry A. (ed.), Regesta Regum Anglo-Normannorum, 10661154: Regesta Henrici Primi, 1066-1135, Oxford, Clarendon Press, 1956, II, no. 792. For the text, see Haskins, Norman institutions, Appendix F, ${ }^{\circ} 1$, p. 293.

39. BnF, ms nouv. acq. lat. 2500 , p. 18 ( $\mathrm{n}^{\circ}$ VIII), p. 24 ( ${ }^{\circ} \mathrm{XIV}$ ); BnF, ms nouv. acq. lat. 1022, p. 7 ( $\left.\mathrm{n}^{\circ} 8\right)$ (extract from BnF, ms nouv. acq. lat. 2500, p. 18 ( $\mathrm{n}^{\circ}$ viII); Gallia Christiana, XI, Instrumenta, col. 110; Delisle, Léopold (éd.), Recueil des actes de Henri II, roi d'Angleterre et duc de Normandie, 4 vol., Paris, Klincksieck, 1916-1927, I, n ${ }^{\circ}$ LXXX and II, nº DXCI.

40. Jaffé, Philipp (ed.), Regesta pontificum romanorum, 2 vol., (Leipzig, 1885-1888), I, n ${ }^{\circ} 6738$ and 6772.

41. Ivo of Chartres, Ep. cClXx, Migne, Jacques-Paul (éd.), Patrologia latina cursus completus, 221, vol., Paris, 1844-1864, CLXII, cols. 273-274 (hereafter Migne, PL).

42. Spear, David, "Geoffrey Brito, archbishop of Rouen (1111-1128)", Haskins Society Journal, 2, 1990, p. $123-137$, at p. 133 .

43. BAYLÉ, Maylis, "Les évêques et l'architecture normande au XI' siècle", in Les évêques..., p. 151172 , at p. 158-161.

44. Gallia Christiana, xI, col. 467. 


\section{The cartulary of Avranches cathedral (Livre vert)}

The cartulary of Avranches has been the subject of only one study, and has never been the subject of a critical edition ${ }^{45}$. Begun in 1241, the cartulary contains acts dating from the twelfth to fifteenth centuries, some of which are written in Latin and others in Old French. The codex itself measures $30 \mathrm{~cm}$ in length, $22 \mathrm{~cm}$ in width, and is comprised of 163 folia. Michèle Lebrun divided the cartulary into four sections, of which the first two (fol. 1-21v and 22-50) are of interest here. The text up to folio 50 is in a uniform hand which is quite large, and, when the parchment is not damaged, easily deciphered. Each section of the manuscript (except the fourth) is preceded by an inventory of the charters (the acts are numbered), and in the first two sections rubrication explains each charter's contents. The folia are numbered twice. The pagination written in red ink and in Roman numerals is the original, while the foliation in Arabic numerals dates to the late nineteenth century. Since modern authorities maintain the latter, it will also be used here.

\section{The charters}

The first scholar to discuss the creation of the deanship by Turgis was the abbot Jean-Jacques Desroches. In his three part "Annales religieuses", he noted the following:

L'évêque d'Avranches [Turgis] nomma doyen du chapitre de son église Richard de Subligny, et ce fut le premier qui occupa cette place honorable. Le Livre vert de la cathédrale, conservé jusqu'à nos jours, va nous fournir maintenant des renseignements plein d'intérêt; il nous apprend que c'était l'évêque Turgis qui avait fondé cette dignité, que Richard de Suligny (ou Subligny) était un homme noble, très distingué par sa modération et sa sobriété, et d'une grande espérance; que les revenus de cette prébende consistaient dans l'église de Vains et dans son cimetière; dans les dîmes des trois vavasseurs Guillaume, Roger et les fils de Girou, et dans la masure du même Girou avec sa dîme. De plus, cette prébende possedait encore une pelisse grise que devait l'abbé du MontSt.-Michel, la dimes des vignes de Champ-du-Bout qui appartenaient à l'évêque, et plusieurs autres revenus sur le manoir de St.-Philbert. Richard de Subligny ajouta de son patrimoine, du consentement de son frère, la dime de $\mathrm{To}^{46}$.

Desroches repeated this claim on at least one other occasion, but provided no exact reference ${ }^{47}$. It was the former of these two citations that David Spear

45. Lebrun, Michèle, Le temporel des évêques d'Avranches du XI au XIV siècle, Diplôme d'Études Supérieures d'histoire, université de Caen, s.d., 168 p. (dactyl.). The charters under consideration here are transcribed on p. 14, 61-62. A summary of this mémoire was published in LEBRUN, Michèle, "Le temporel des évêques d'Avranches du XI e au XIII" siècle", Revue de l'Avranchin et du Pays de Granville, 42, 1965, p. 58-80.

46. Desroches, “Annales religieuses...", I, p. 428-429.

47. Desroches, Jean-Jacques, "Sur les paroisses du Mont-Saint-Michel”, Mémoires de la Société des antiquaires de Normandie, 14, 1844, p. 37-128, at p. 49. 
included in his fasti of Norman cathedral personnel, but he reported that he had "been unable to locate" the charter in question ${ }^{48}$. Elsewhere, Édouard Le Héricher, former president of the Société Archéologique et Historique d'Avranches, referenced what he claimed was the same act in his architectural and historical study of the Avranchin ${ }^{49}$. Fortunately, Le Héricher provided not only a full reference (he held that the act was on page 23 of the cartulary), but also a partial transcription of the act ${ }^{50}$.

The charter to which both Desroches and Le Héricher referred is actually a confirmation of Hugh of Amiens, archbishop of Rouen (1130-1164). It appears on folia $8 \mathrm{v}$ to 9 of the cartulary ${ }^{51}$. Unfortunately, Le Héricher did not identify the act as such (he thought it was a charter of Richard de Subligny (1143-1153) and mistakenly dated it to the thirteenth century), but the text of his transcription (as well as his reference to p. 23 (fol. 8v)) confirms that he cannot have been looking at another act ${ }^{52}$. Thomas Waldman, whose doctoral thesis on Hugh of Amiens contains a superb collection of the archbishop's acta, was unaware of the charter, since it is not found among his editions ${ }^{53}$. This is significant, since the confirmation on these folia is one of two in the cartulary issued by Hugh of Amiens which relate to the founding of the deanship by Turgis, and their edition and analysis here adds to our knowledge of his acta.

The first confirmation corresponds to Desroches' summary. It is addressed to Richard de Beaufou, bishop of Avranches (1134-1143), Richard the dean, who must be Richard de Subligny, the archdeacons (unnamed), and chapter of Avranches ${ }^{54}$. The opening section is then followed by the text of a charter issued by Richard de Beaufou, in which he and the dean Richard de Subligny record that the deanship was founded by the "illustrious and pious bishop Turgis" (ab illustri et pie recordationis episcopo Turgisio), and that attached to the prebend was the church of Vains (Saint-Pierre) with its cemetery ${ }^{55}$, the tithes of three vavassors (William, Roger, Girard and his sons), the tithes of the vineyards of campo Botri, and various revenues from the manor at Saint-Philbert-

48. SPeAR, The personnel..., p. 6.

49. LE HÉRICHER, Edouard, Avranchin monumental et historique, 3 vol., Avranches, Tostain, 18451865 , I, p. 178-179.

50. Le Héricher referenced using the pagination, since the foliation used by modern scholars was not added in the cartulary until 1884; Le Héricher, Avranchin monumental..., I, p. 179 note 1.

51. Appendix, $\mathrm{n}^{\circ}$ 1.

52. “L'église de Saint-Pierre-de-Vains fut donnée au XII" siècle par l'évêque d'Avranches, Turgis, à ses chanoines; cette donation fut confirmée au commencement du XIII siècle par Richard de Subligny..."; Le HÉRICHER, Avranchin monumental..., I, p. 178.

53. Waldman, Thomas G., "Hugh 'of Amiens', archbishop of Rouen, 1130-1164”, unpublished D. Phil thesis, University of Oxford, 1971, 648 p. (dactyl.). The charters are edited on p. 168-561. The Livre vert is not cited among the extensive list of manuscripts consulted by Waldman (p. 563-569).

54. For the career of Richard de Beaufou, see FournéE, Jean, "Notes sur un évêque d'Avranches au XII siècle: Richard de Beaufou (1134-1143)", Revue de l'Avranchin et du pays de Granville, 33, 1946, p. 359-364. Cf. also a short monograph by the same author on the family of de Beaufou; Une ancienne famille de Normandie: de Beaufou, Paris, 1946, p. 1-42, esp. 12-14. I am particularly grateful to Véronique Gazeau for allowing me to consult a copy of this unpublished work.

55. Vains, dép. Manche, cant. Avranches. 
(sur-Risle) ${ }^{56}$, including the tithes of the mills atAccurso (unidentified),Tolwio (see below), and Livet-(sur-Authou) ${ }^{57}$. It is then recorded that Richard de Subligny added to the prebend the tithes of Choeio (see below), which belonged to his brother's fief (de feodo fratris sui). This is then followed by a later confirmation of Hugh de Morville, bishop of Coutances (1208-1238) and a John, bishop of Dol, and his chapter (see below).

Archbishop Hugh's second confirmation, which appears on folio $34-\mathrm{v}$ of the cartulary, opens with essentially the same text as the first act ${ }^{58}$. Unlike the first charter, however, it is not followed by the act of Richard de Beaufou, but rather by a brief statement that those who would violate the terms of the deanship are subject to anathema. There then follows a witness list that includes the archbishop himself, Richard de Beaufou, Arnulf, bishop of Lisieux (11411181), Waleran, dean of Rouen (c. 1137-c. 1146), Geoffrey, archdeacon of Rouen (1133-1148), Osmund II, archdeacon of Rouen (1111x1115-1158), Bernard, abbot of Mont-Saint-Michel (1131-1149), Fraternus, abbot of Saint-Ouen de Rouen (after 12 June $1141 \mathrm{x}$ before 1 Aug. 1142-1157), Rodulf, abbot of La Croix-Saint-Leufroy (before 1143-after 1158), and three archdeacons, two of whom, Fulbert III (c. 1124c. 1158) and Giles (1138-1170), were attached to the church of Rouen, while the third could either be Hugh de Fréuville, archdeacon of Rouen (c. 1138-c. 1158), or Hugh de Lingèvres, archdeacon of Avranches (1142) ${ }^{59}$. Based on these dates, the charter was probably produced in around 1142, and certainly no later than 25 April 1143 (de Beaufou's death). If it was issued at this time, it was undoubtedly related to the increasing influence of Geoffrey of Anjou in the duchy. On 6 April 1141 he had seized Lisieux from its bishop, and by 1142 he had captured both Avranches and Coutances ${ }^{60}$. According to John of Marmoutier, the count of Anjou was met by Richard de Beaufou as he approached the city, and the two men walked to the cathedral and then the castle, where the bishop officially surrendered the city ${ }^{61}$. Aware that such a dramatic shift in the politics of the duchy could have ramifications for the cathedral's possessions, the chapter had perhaps petitioned the archbishop of Rouen, who still seems to have been supporting King Stephen as late as 1143 , for a second confirmation ${ }^{62}$. The first had

56. Saint-Philbert-sur-Risle, dép. Eure, cant. Montfort-sur-Risle.

57. Livet-sur-Authou, dép. Eure, cant. Brionne. The identification is that of Michèle Lebrun; Lebrun, "Le temporel...", p. 75.

58. Appendix, $\mathrm{n}^{\circ} 2$.

59. The dates of tenure for the cathedral dignitaries are based on those in SPEAR, The personnel..., p. 9, 201, 210-212. For the abbots, see GazeAu, Véronique, Normannia monastica. Princes normands et abbés bénédictins ( $X^{e}-X I I^{e}$ siècle), 2 vol., Brepols, Turnhout, 2008, II, p. 88-89, 216-218, 252-255.

60. Chronique de Robert de Torigni, abbé du Mont Saint Michel, éd. Léopold DelisLe, 2 vol., Rouen, A. Le Brument, 1872-1873, I, p. 224, 226-227.

61. John of Marmoutier, "Historia Gaufredi ducis Normannorum et comitis Andegavorum", in Chroniques des comtes d'Anjou et des seigneurs d'Amboise, Louis HALPHEN et René Poupardin (éd.), Paris, Picard, 1913, p. 228.

62. Hugh's support of Stephen is based upon the dating his charters by the king's reign; WALDMAN, "Hugh 'of Amiens'...”, p. 90. 
not made any provisions for those who would violate the terms of the deanship, but the second expressly threatened anathema for such actions, a warning perhaps implicitly intended for the new master of Avranches. Indeed, the cathedral was not the only religious institution in the region to seek the archbishop's protection following the Angevin occupation of the Avranchin ${ }^{63}$. The gathering of men who witnessed the charter probably occurred in Rouen. It was one of the last cities not under Angevin control at this time, and was home to eight of the twelve witnesses. Moreover, we know that Arnulf, bishop of Lisieux, was in Rouen in 1142 conducting diocesan business ${ }^{64}$, although he had not yet been recognised by Geoffrey of Anjou ${ }^{65}$.

The diplomatic value of Hugh's charters has already been discussed in detail by Thomas Waldman ${ }^{66}$. Although these two additional acts represent only one percent of the total number of charters issued by the archbishop, they are not without their importance to our understanding of this body of texts. The second confirmation, for example, allows us to refute the claim that Richard de Beaufou never witnessed for Hugh ${ }^{67}$. More interesting still is the act's anathema clause:

Quisquis vero contra hanc nostre constitutionis paginam scienter venire temptauerit, nisi pie que incepit, corrigere procurauerit, sciat se anathemati subiciendur, et gravi iactura plectandum.

Although many of Hugh's acts contain penal clauses, of the 158 charters edited by Thomas Waldman, only 25 (about $15 \%$ ) make specific reference to anathema ${ }^{68}$. The penal clause above is also distinctive for its use of the phrase venire temptauerit, which appears in only a handful of Hugh's charters, the majority of which date to within four or five years of $1142^{69}$. The phrase is found most often in papal documents, and among Hugh's charters is limited to use in confirmations, a number of which Waldman held were "papal" in style ${ }^{70}$. The papal influence on Hugh's charters is well known, and includes the use of

63. Hugh of Amiens sent a letter to the bishop of Avranches asking that he protect the monks and possessions of Savigny. It is possible this document was aimed at the followers of Geoffrey of Anjou; Waldman, "Hugh 'of Amiens'...", “The Acta of Hugh 'of Amiens”", n 16o, p. 515-516, at p. 516.

64. Schriber, Carolyn, The dilemma of Arnulf of Lisieux : new ideas versus old ideals, Bloomington, Indiana University Press, 1990, "The itinerary of Arnulf of Lisieux", p. 126.

65. Arnulf was finally recognised by Geoffrey in 1143 after he had paid the duke 900 livres; BARLOw, Frank (ed.), The letters of Arnulf of Lisieux, London, Offices of the Royal Historical Society, 1939, p. 209.

66. Waldman, "Hugh 'of Amiens'...”, p. 125-146.

67. Ibidem, p. 92.

68. Ibidem, "The Acta of Hugh 'of Amiens"”, $\mathrm{n}^{\circ}$ 14, 16, 36, 56, 80, 86, 101, 112, 114, 118, 128, 131, 132, 133 $134,135,136,140,141-143,147,149,156$ and 168.

69. Ibidem, "The Acta of Hugh 'of Amiens"”, $\mathrm{n}^{\circ}$ 8, 9, 33, 58, 60, 147, 150, 151, 157. All these charters date to either $1137,1141,1142$ and 1145 . Three charters use the phrase and date from slightly later, but two of these ( $\mathrm{n}^{\circ} 46(1154)$ and 61 (1155?) are based on earlier documents ( $\mathrm{n}^{\circ} 33$ and 60), while the other dates to 1151 ( $\left.\mathrm{n}^{\circ} 129\right)$.

70. Ibidem, "The Acta of Hugh 'of Amiens"”, n 60, 61, 147, 150 and 151. 
Roman formulas for blessings and anathema ${ }^{71}$. It seems fairly certain, therefore, that the original charters were produced by the Rouen chancery, rather than that at Avranches. The closing words of the anathema clause (et gravi iactura plectandum) are unknown among Hugh's charters, however. The unusual word is plectandum, which is a derivative of the verb plecto ('to beat', 'to punish'). Only one of Hugh's charters contains a variant of this word (plectetur) ${ }^{72}$, and since the form plectandum is almost unknown, it is perhaps a corruption of the passive subjunctive plectandur ('they may be punished') ${ }^{73}$. Unfortunately, there is nothing else to link this charter and that containing the form plectetur, which was issued for the abbey of Montebourg between c. 1153 and c. $1157^{74}$. Nevertheless, perhaps what is most interesting about the two confirmations is how long they maintained their currency after they had been issued. The Avranches chapter never seems to have wanted to replace them with the confirmation of a later archbishop of Rouen, and when figures of the thirteenth and fourteenth centuries came to confirm the deanship, it was the veracity of Hugh's charters that they endorsed.

It is possible that the third charter in the Livre vert concerning the deanship was also produced in response to the new Angevin presence in the region. Issued by Richard de Subligny, it appears on folia 33v-34, just before the second confirmation of Hugh of Amiens, and perhaps dates to the first year of the bishop's reign ${ }^{75}$. Like Hugh's confirmation, it once again threatens anathema, but also places the deanship under the protection of the Apostles Andrew, Peter and Paul. Besides the summoning of these celestial heavyweights, the charter's only other distinctive feature is that the rubricator has incorrectly labelled it as the confirmation of Hugh of Amiens, and vice versa. This was a mistake that apparently went unnoticed until the fifteenth century, when a scribe, whose hand appears later in the codex, noted the correction in the margin. It is, however, not the only inconsistency relating to the charter's classification, for the inventory which details the charters found in the second part of the cartulary contains the following confusing entry ${ }^{76}$ :

71. Ibidem, "Hugh 'of Amiens'...”, p. 126-128, 133, 136.

72. Ibidem, "Hugh 'of Amiens'...", "The Acta of Hugh 'of Amiens"”, n 80

73. The word is not found in any royal or ducal charter of the eleventh and twelfth centuries, and is not among any of the more than 1,700 Norman acts currently entered in the database SCRIPTA, which is being compiled under the direction of $\mathrm{M}$. Pierre Bauduin at the Centre de recherches archéologiques et historiques médiévales (CRAHM) of the Université de Caen Basse-Normandie. Furthermore, it occurs only once in the two hundred and seventeen volumes of Patrologia Latina, and this is in an index compiled by Jacques-Paul Migne for William of Malmesbury's, Gesta regum Anglorum; "Comitem ob proditionis crimen morte plectandum jubet"; Migne, PL, CLXxIX, col. 1854. The comes in question is Waltheof, earl of Northumbria (d. 1076), but Malmesbury does not use a derivative of the verb plecto to describe his execution by beheading; Mynors, Roger A.B. (ed.), William of Malmesbury, Gesta regum Anglorum, 2 vol., Oxford, Clarendon Press, 19981999, I, p. 468-470.

74. Waldman, "Hugh 'of Amiens'...", “The Acta of Hugh 'of Amiens"”, n 80.

75. Appendix, $\mathrm{n}^{\circ} 3$.

76. Bibl. mun. d'Avranches, $\mathrm{ms}$ 206, $\mathrm{f}^{\circ} .23$. 
xxxix Carta de Turgisio decano et Ricardo episcopo propter decanatum.

xl Littera et confirmatio Hugonis archiepiscopi Rothomagensis super constitucionem decanatus ecclesie Abrincensis

xli Littera et confirmatio Richardi episcopi super constitutionem decanatus ecclesie Abrincensis

xlii Littera et confirmatio Baiocensis episcopi super decanatum ecclesie Abrincensis

The problem is that the numbering of the inventory does not correspond with the numbers assigned to the charter texts, except for that which is numbered $x l$. The charter numbered $x l i$, and which claims to be a confirmation of a bishop Richard, is actually the charter that includes, among others, an inspeximus of the bishop of Bayeux, which is numbered xlii in the inventory ${ }^{77}$. The charter numbered xxxix could refer to the charter of Richard de Subligny on folia 33v-34, but the description seems to suggest otherwise. Indeed, the charter that has been given the number $x l i$ in the inventory, and which is listed after the confirmation of Hugh of Amiens, is a more accurate description of our charter, since it refers to the act as a confirmatio. However, the text of the charter of Richard de Subligny is numbered xxxix. Two conclusions can be reached from this. Either the scribe, who produced both the inventory and main body of text simply described and numbered Richard de Subligny's charter twice (no. xxxix and $x l i$ ), only to realise that he had only one charter (which was then given the number xxxix in the main text), or, the charters numbered xxxix and $x l i$ are actually two different texts, one of which (most likely that numbered xxxix in the inventory) was not included in the cartulary. Such discrepancies provide what might be fleeting evidence of a now lost charter, although these are not the only inconsistencies between the inventories and the main body of charter texts ${ }^{78}$.

The fourth charter concerning the deanship is found on folio $34 \mathrm{~V}$, and is comprised of four different inspeximus ${ }^{79}$. This style of confirmation, which began to evolve in the second half of the twelfth century, has long presented special problems for diplomatists ${ }^{80}$. The first raised by our example is whether the

77. The charter text numbered xlii is actually a charter of Richard de Subligny's brother, Hasculf; Bibl. mun. Avranches, ms 206, fol. 34v (Appendix n ${ }^{\circ}$ ).

78. Lebrun, "Le temporel [diplôme]...", p. 1-2

79. Appendix, $n^{\circ} 4$.

80. For the history of the inspeximus and its related forms, see GIRY, Arthur, Manuel de diplomatique, Paris, Hachette, 1894, p. 14-26; CHeney, Christopher, English bishops' chanceries, 1100-1250, Manchester, Manchester University Press, 1950, p. 90-96; Bresslau, Harry, Handbuch der Urkundenlehre für Deutschland und Italien, 3 vol., Berlin, Gruyter, 1958-1968, II, p. 301-325; GuYotjeAnNin, Olivier, Pyске, Jacques, and Тоск, Benoît-Michel, Diplomatique médiévale, Turnhout, Brepols ("L'atelier du médiéviste", 2), 1993, p. 166, 212, 286-287, 328, 385-39o. For an analysis of the difficulties encountered by historians when using inspeximus with regard to English royal charters, see Vincent, Nicholas, "The charters of King Henry II: the introduction of the royal inspeximus revisited", in Dating undated medieval charters, Michael Gervers (éd.), Rochester, NY, Boydell Press, 2000, p. 97-120. 
inspeximus should, in reality, be considered as a separate act at all. Those responsible for compiling the cartulary clearly felt that they should, for not only was the act numbered ( $x l i$ ), but it was also entitled by the rubricator (Littera episcopi Baiocensis super decanatu ecclesie Abrincensis) ${ }^{81}$. This description is highly misleading, however, for the text, which immediately follows the second confirmation of Hugh of Amiens, is no more a charter of the bishop of Bayeux than the inspeximus issued by later bishops for Hugh's first confirmation can be called a charter of the bishop of Coutances. Why the scribe decided to make a distinction between these inspeximus and the charter to which they relate, whereas he had previously kept these two parts together, is a question that can, unfortunately, never be answered.

The second problem relates to the identity of those responsible for the inspeximus, the first of which was issued by a certain $R$. Baiocensis episcopus. Michèle Lebrun did not hesitate to expand the R. to Ricardus, which would make the bishop Richard of Gloucester $(1135-1142)^{82}$. This identification is acceptable, however, only if one assumes that the next inspeximus, issued by a dean of Bayeux named William, was made at a different time than the one that precedes it. Otherwise, we are forced to consider a different identity either for the bishop or the dean, or perhaps both. Three Williams were dean at the cathedral during the ducal period ${ }^{83}$. William de Rots, who according to Orderic was simultaneously dean, chanter and archdeacon of Bayeux, had left the cathedral to become a monk at Saint-Étienne de Caen at a date before 1080, and eventually became abbot of Fécamp ${ }^{84}$. The second William first appears on 7 May 1092, while he was dead by $1113^{85}$. William de Tournebu was the last dean during the ducal period to carry the name, but his first known appearance dates to 3 March $1153^{86}$. In 1184 he was consecrated bishop of Coutances, a position that he held until 1202. Even if he were just of canonical age in 1153, he would have died a man of seventy-nine. If it was he who issued the inspeximus, he must have done so at a date before 1142 (Richard of Gloucester's death), which means he would have died a man anywhere between ninety and one hundred years of age ${ }^{87}$ ! Consequently, none of the three deans called William could have issued an inspeximus at the same time as that delivered by an R. Baiocensis episcopus identified as Richard of Gloucester. However, since the position of dean was never held simultaneously by two individuals, the William of our charter could be a previously unknown

81. As can be seen above, the scribe responsible for the cartulary's inventory went even further in his description of the act, calling it both 'littera' and 'confirmatio'; Bibl. mun. d'Avranches, ms 206, fol. 23.

82. Lebrun, "Le temporel [diplôme]...", p. 62.

83. For what follows, see SpeAR, The personnel..., p. 34-35.

84. OV, II, p. 138-140, 150 and 292.

85. Bourrienne, Valentin (éd.), Antiquus cartularius ecclesioe Baiocensis (livre noir), 2 vol., Société de l'histoire de Normandie, 1902-1903, I, nºxiI.

86. Ibidem, Antiquus..., I, $\mathrm{n}^{\circ} \mathrm{CxxxIx}$.

87. This figure is calculated once again by assuming that had he witnessed the charter at a date before 1142 , he would have been at least thirty years old. 
occupant of the position who was dean between Ralph, whose last occurrence datable to a single year is in 1135, and Richard de Bohon, who first appears in 1144. This would not only confirm that the first inspeximus was issued by Richard of Gloucester, but would require that the succession of deans at Bayeux should be rewritten as follows: William I (de Rots), 13 September 1077-c. 1080; William II, 7 May 1092-1113; Ralph, 1107X1133-1135; William III, 1135x1144; Richard de Bohon, 1144-1151; William IV (de Tournebu), 3 March 1153-1184.

It is possible, of course, that the bishop of Bayeux is Robert des Ablèges (1206-1231). This would make the dean William IV (not the IV in our reckoning), who occupied the position from 1213 to $1226^{88}$. Indeed, the use of words in the charter such as 'originalis' and 'sustinencia', which, along with the inspeximus form itself, are rare for the twelfth century ${ }^{89}$, might indicate that the scribe either made a poor copy of an earlier charter, or was working from a document dating from a later century ${ }^{90}$. We have already seen how the first confirmation issued by Hugh of Amiens was later confirmed by figures of the thirteenth century, while our charter was subject to two other later inspeximus. The first of these was issued by the community at Saint-Lô (conventus sancti Laudi dyocesis Constanciensis). Unfortunately, there is no indication at what time this inspeximus

88. Gallia Christiana, XI, col. 399. The only other medieval dean of Bayeux called William was William le Bailleul, who was dean from 9 November 1444 to 16 February 1482; Gallia Christiana, XI, col. 401-402.

89. The inspeximus first appeared in the English dioceses of Worcester, London, Bath and York in the 117os; Cheney, Christopher and Jones, Bridgett (ed.), English episcopal acta II, Canterbury, 1162-119o, Oxford, Oxford University Press, 1991, p. lxvi-lxvii. Only three Norman dioceses have had their charters edited to such an extent that similar developments can be traced with any certainty. At Évreux, the inspeximus did not really become current until the thirteenth century, although from the 1170 on onwards documents were being examined by the bishop ("...inspectis instrumentis et presumptionibus"); СомваLBERT, Grégory (éd.), “Chartes des évêques d'Évreux (911-1223)", Mémoire de maîtrise, Université de Caen, 2004, no. 65. The picture is fairly similar in Coutances, where a charter dated 5 February 1187 is the first to use such language ("sicut ex carte sue inspectione"); FonTANEL, Julie (éd.), Le cartulaire du chapitre cathédral de Coutances: étude et édition critique, Saint-Lô, Archives départementales de la Manche, 2003, no. 103. For the development of this practice at Bayeux, see below p. 15 n. 96.

90. The word originalis, or a variant therefore, appears in charters dating from the beginning of the eleventh century through to the early fourteenth; Fauroux, Recueil..., $\mathrm{n}^{\circ} 42$ (dated 1015x1026; SCRIPTA, Acte $\mathrm{n}^{\circ}$ 1487); Société jersiaise (éd.), Cartulaire de Jersey: recueil de documents concernant l'histoire de l'île, Jersey, J.W. Labey, 1918-1924, $\mathrm{n}^{\circ} 9$ (dated 1150; SCRIPTA, Acte $\mathrm{n}^{\circ}$ 3001); Laffleur de Kermaingant, Pierre Paul (éd.), Cartulaire de l'abbaye de Saint-Michel du Tréport, Paris, Typ. de Firmin-Didot et Cie., 1880, $n^{\circ}$ XVIII (dated 1151; SCRIPTA, Acte $n^{\circ} 575$ ); Le Cacheux, Marie-Josèphe, Histoire de l'Abbaye Saint-Amand de Rouen: des origines à la fin du XVI siècle, Caen, Société d'impression de Basse-Normandie, 1937, n IV, p. 254-258 (dated 17 Dec. 1191; SCRIPTA, Acte ${ }^{\circ}$ 2350); Gallia Christiana, XI, Instrumenta, cols. 263-270 (dated 1316; SCRIPTA, Acte $n^{\circ}$ 1911). The term sustinentia/sustinencia is restricted more to the late twelfth or early thirteenth century, but is, interestingly, found most often in documents from Bayeux issued by Robert des Ablèges; Bonnin, Théodose (éd.), Cartulaire de Louviers: documents historiques originaux $d u X^{e}$ au XVIII ${ }^{e}$ siècle, 6 vol., Évreux, Hérissey, 1870-1873, n LXXV (dated 1197; SCRIPTA, Acte ${ }^{\circ}$ 2015); Ibidem, Cartulaire de Louviers..., $\mathrm{n}^{\circ}$ CXII (dated 24 March 1206; SCRIPTA, Acte $n^{\circ}$ 2033); Bourrienne, Antiquus..., I, n CCXXI (dated 24 July 1221; SCRIPTA, Acte $\mathrm{n}^{\circ}$ 1011); Ibidem, Antiquus..., II, $\mathrm{n}^{\circ}$ CCCXXXVII (dated 1213X1226; SCRIPTA, Acte $\mathrm{n}^{\circ} 1127$ ); Ibidem, Antiquus..., II, n CCCI (dated 1235; SCRIPTA, Acte $\mathrm{n}^{\circ}$ 1092). 
was made, although it was not until the mid-twelfth century (around 1145) that the abbey of Sainte-Croix had its first abbot (Theoderic), having been turned into a community of regular canons by Algar, bishop of Coutances (1132-1151), in the $1130 \mathrm{~s}^{91}$. There is no reference to the confirmation in the abbey's cartulary ${ }^{92}$. The other inspeximus was made by a certain Sylvester, who is said to be an abbot of Lessay. The only abbot by this name, however, comes from the early fourteenth century (c. 1321-c. 1337), and his career is remarkable only for a sole appearance in $1329^{93}$. Véronique Gazeau has established the abbatial succession at Lessay for the ducal period, and there was not another occupant of the position with this name during this time ${ }^{94}$. It is possible that the cartulary scribe wrote Sylvester in error for another name, but with many of his predecessors and successors having such standard Norman monikers as William, Warner, Robert, Roger and Rodulf, it is difficult to see with which of these he was confused. His presence demands, therefore, that we revaluate the dates assigned to this part of the cartulary, which Michèle Lebrun claimed contained no charters dating beyond $1290^{95}$. It seems likely that the Bayeux charter therefore dates to the early thirteenth century. However, since the cartulary scribes reproduced this and other charters with errors, and given the complex nature of this type of act and the fact that words emphasising personal examination are not uncommon in early Bayeux episcopal charters ${ }^{96}$, we cannot dismiss the idea that the first inspeximus was issued by an earlier bishop.

The final twelfth-century charter concerning the deanship also appears on folio $34 \mathrm{~V}^{97}$. It was issued by Hasculf de Subligny, the brother of the bishop of Avranches, and is a confirmation of the "two sheaves of Toi, which my brother Richard, bishop of blessed memory, had had while dean" ${ }^{98}$. As the quote noted

91. Innocent II wrote to Algar about his efforts to install canons at Saint-Lô; Gallia Christiana, XI, Instrumenta, col. 238. For the abbey's early history, see Gallia Christiana, XI, col. 936; Gerville, Charles Duhérissier (de), "Recherches sur les abbayes du département de la Manche", Mémoires de la Société des antiquaires de Normandie 2, Caen, 1826, p. 25-140, at p. 94-101; TousTAIN DE Billy, René, Histoire ecclésiastique du diocèse de Coutances, 3 vol., Société de l'histoire de Normandie, 1874, I, p. 180-182.

92. Dubosc, François-Nicolas (ed.), Cartulaire de l'abbaye de Saint-Lô, Saint-Lô, 1882, 95 p.

93. Gallia Christiana, xI, col. 920 .

94. Cf. GazeAu, Normannia monastica...., II, p. 171-176.

95. Lebrun, "Le temporel [diplôme]...", p. 3-4.

96. The first definitive example of the language of the inspeximus as it would be in the thirteenth century dates from as early as the 1160 ("Quod vidimus et audivimus fiducialiter loquimur et attestamur"; Dupuy, Hubert (éd.), "Recueil des actes des évêques de Bayeux antérieurs à 1205", 2 vol., Thèse École des chartes, Paris, 1970, II, no. 143), although words that emphasise personal examination form a regular part of Bayeux charters from the late 109os onwards; "Ego Odo Baiocensis episcopus hanc chartam lectam et perlectam confirmo et subscribo" (Ibidem, "Recueil de Bayeux...", I, no. 10; dated 24 May 1096); "Lecta est autem hec carta in capitulo Baiocensi..." (Ibidem, "Recueil de Bayeux...", I, no. 66; dated 1164x1177); "Ex inspectione litterarum Engerrami Patric..." (Ibidem, "Recueil de Bayeux...", II, no. 104; dated 1174X1190); "Inde est quod nos, inspecta carta Ricardi Silvein..." (Ibidem, "Recueil de Bayeux...”, II, no. 113; dated 1174X1190).

97. Appendix, $\mathrm{n}^{\circ} 5$

98. “...duas garbas de Toi quas Ricardus frater meus pie recordacionis episcopus habuerat dum decanus". 
above demonstrates, Desroches believed that this donation was the same as that of Choeio / Toeio, which is stipulated in the confirmations of Hugh of Amiens and Richard de Subligny. Émile-Auber Pigeon noted that Hasculf had given to the chapter the tithes of Thoué, in the commune of Lolif, which Michèle Lebrun held the bishops of Avranches had possessed since the eleventh century ${ }^{99}$, although frustratingly Pigeon did not specify which act in the cartulary he was interpreting ${ }^{100}$. Elsewhere, one could identify Toi as Toit, which was tentatively linked by David Bates with Le Tuit, a dependancy of Berville-en-Roumois. This toponym appears in a charter for the abbey of Bec, ${ }^{101}$ and is close to other benefices (approx. $11 \mathrm{~km}$ ) associated with the deanship, namely those located at PontAuthou (the mills atAccurso andTolwio), which were also later associated with the same abbey ${ }^{102}$. The foundation charter of La Lucerne d'Outremer confirms, however, that Toi was within Subligny itself ${ }^{103}$.

It remains to be determined, of course, if Toi and Choeio / Toeio are the same place. Unfortunately, the onomastic evidence is inconclusive. One need only look at the myriad forms for Vains in the eleventh and twelfth centuries (Veim, Vein, Vehim, Vehin, Vehein, Vedun) to see how inconsistently scribes rendered the name of an important local settlement ${ }^{104}$. Toi, however, appears in the cartulary three times and the form is always fairly uniform (Toe, Toy and Toi ${ }^{105}$. Moreover, the charter of La Lucerne also uses the form Toi, which suggests that this was its recognised rendering among local scribes ${ }^{106}$. In his etymological study of regional toponyms, Marie-Joseph Masselin claimed that Thoué is the modern rendering of Toi, but unfortunately he did not specify the location of this particular place. He does seem to suggest, however, that the ancient form of Thoué was Toi, and Toi alone ${ }^{107}$, although Michèle Lebrun, who transcribed Choeio as Thoeio in the confirmation of Hugh of Amiens, believed that

99. Lebrun, "Le temporel...", p. 71. I have been unable to locate the document on which Lebrun based this assertion.

100. Lolif, dép. Manche, cant. Sartilly; Pigeon, Le diocèse d'Avranches..., II, p. 341.

101. Berville-en-Roumois, dép. Eure, cant. Bourgtheroulde-Infreville; BAtes, David, (ed.), Regesta regum Anglo-Normannorum : the Acta of William I, 1066-1087, Oxford, Clarendon Press, 1998, $\mathrm{n}^{\circ}$ 166. For the identification, see "Index Personarum et Locorum", p. 1140.

102. For the identification and association with Bec, see LeBrUn, "Le temporel...", p. 75.

103. "In Suligneio vineam de Toi..."; Gallia Christiana, XI, Instrumenta, cols. 112-113, at col. 113.

104. For bibliographic details of these different forms, and a discussion of the origins of the name Vains, see Bouvris, Jean-Michel, “Aux origines du prieuré de Vains: une version inédite de la confirmation par le duc Robert Courte-Heuse d'une donation faite en 1087 par Guillaume le Conquérant à l'abbaye de Saint-Etienne de Caen", Revue de l'Avranchin et du pays de Granville, 64, 1987 , p. 3-21, 67-9o, at p. 10-12.

105. Bibl. mun. Avranches, ms 206, fol. 23, 34v.

106. This is the only appearance of To $i$ in a Lucerne document. It is not found among those charters edited by François-N. Dubosc, although he was working without the lost cartulary known as the Livre noir, which the editors of Gallia Christiana had access to. For the history of this cartulary, see Dubosc, François-N. (éd.), Cartulaire de l'abbaye de la Lucerne, Saint-Lô, 1878, p. I-v, esp. p. I.

107. Masselin, Marie-Joseph, "Études sur les étymologies des noms de lieux et des noms de famille dans l'Avranchin: Table de ces étymologies par ordre alphabétique", Mémoires de la Société archéologique d'Avranches, 12, 1894-1895, p. 127-227, at p. 219. 
this was the Latin rendering of Thoué in Lolif ${ }^{108}$. Until more conclusive evidence is found it is possible that the place known as Choeio / Toeio is different from Toi, but since this form is absent from both national and regional onomastical studies it must remain unidentified ${ }^{109}$.

Fortunately, we can be more certain about the charter's dates. It must have been issued after 1162, since it refers to the dean Rolland (who first appears on 8 April of that year), but before Hasculf's death in $1169^{110}$. The act was witnessed by various figures, including Rannulf de Presles ${ }^{111}$, Alan d'Île, Peter of Verdun ${ }^{112}$, and William, son of Auger, although their presence does not allow for a more exact dating. All except William were descendants of Domesday tenantsin-chief, and were members of families that had a presence in both England and Normandy. Only Rannulf can be traced with any certainty ${ }^{113}$. There were two twelfth-century figures of the de Presles family named Rannulf. According to a charter of the abbey of Troarn, the first was the son of a certain Turstin (not listed by Keats-Rohan) ${ }^{114}$, and the brother of Robert, who died a monk of this same house in c. $1120^{115}$. The other was the son of Matthew de Presles and his wife Beatrice. Matthew was a tenant of the earls of Chester, who were also the vicomtes of Avranches, as was his son, who succeeded him by c. 1180. Since members of Hasculf's family were themselves tenants of the earls of Chester, it is likely that this Rannulf witnessed our charter. What prompted the confirmation at this particular time is unclear. It may have been the result of a dispute between the cathedral chapter and another religious institution over this benefice. Indeed, the chapter and abbey of Mont-Saint-Michel were involved in a dispute over the grey pilch (pellicia grisia) ${ }^{116}$, which the abbot owed annually to the dean, and when this matter was settled by Hugh de Morville, bishop of Coutances, in 1213, it was perhaps at this time that he issued his inspeximus of Hugh of Amien's first confirmation ${ }^{117}$. It is even possible that if Robert des Ablèges

108. Lebrun, Le temporel [diplôme]..., p. 14; Lebrun, Le temporel..., p. 71.

109. Furthermore, the name Toi has not survived among any of the many hamlets in modern-day Subligny; INSEE. Direction régionale (Rouen), Nomenclature des hameaux: écarts et lieux-dits du département de la Manche, Rouen, INSEE, 1961, $2^{\mathrm{e}}$ partie, p. 149-150.

110. Robert of Torigni, Chronique..., II, p. 12.

111. Presles, dép. Calvados, cant. Vassy.

112. Verdun, dép. Manche, in Vessey, cant. Pontorson.

113. For what follows, see Keats-Rohan, Katherine S.B. (ed.), Domesday people: a prosopography of persons occurring in English documents 1066-1166. 1, Domesday book, Woodbridge, Boydell Press,1999, p. 168, 275, 360; Keats-Rohan, Katherine S.B. (ed.), Domesday descendants: a prosopography of persons occurring in English documents 1066-1166, II, Pipe rolls to Cartae baronum, Woodbridge, Boydell Press, 2002, p. 525-526, 649-650, 765-766.

114. SAuvage, René Norbert, L'Abbaye de Saint-Martin de Troarn au diocèse de Bayeux des origines au seizième siècle, Mémoires de la Société des antiquaires de la Normandie 34, 1911, "Preuves", $\mathrm{n}^{\circ}$ VII, p. 367 .

115. Keats-Rohan, Domesday descendants..., p. 650.

116. A pilch is an outer garment made of animal skin with the fur used as a lining.

117. Bibl. mun. Avranches, ms 206, fol. 35 (Appendix n ${ }^{\circ}$ ). The decision was confirmed by neighbouring abbots in the same year (fol. $35-\mathrm{v}$ ). It is also possible that Hugh issued his confirmation when he visited Mont-Saint-Michel on 30 May 1211. For details, see below p. 22. 
was the bishop responsible for the Bayeux inspeximus discussed above, that his act might also be associated with this event. Unfortunately, no record of any dispute over the tithes granted by Hasculf exists, although the dean Rolland was not unaccustomed to such incidences, and at some point was involved in a dispute with a certain Alan de Saint-Pierre over the tithes of the land of Chantorre ${ }^{118}$.

\section{The deanship: establishment and protection}

The cathedral of Avranches was the last Norman diocese to establish the position of dean ${ }^{119}$. At what point during his reign Turgis actually created the position is unclear, but his choice of benefices for the dean's prebend, and Richard de Subligny as the first dean, cannot have been accidental ${ }^{120}$. The new dean belonged to a powerful local family, which by the early twelfth century had established both secular and religious dynasties in the region ${ }^{121}$. Émile-Auber Pigeon believed that the family patriarch was Otuel, an illegitimate son of Hugh I, earl of Chester ${ }^{122}$, but while there was such an individual, he drowned on the White Ship on 25 November $1120^{123}$. The idea, nevertheless, persists ${ }^{124}$. Alternatively, it has been argued that while the family later held land at and around Subligny ${ }^{125}$, they were actually of Breton origin, and that their toponym (rendered Suligny) came rather from the region between Pontorson (where there is a hamlet called Soligné in the commune of Tanis) ${ }^{126}$ and Saint-James (de Beuvron) ${ }^{127}$. Richard de Subligny had two brothers (Rodulf and Hasculf, styled Harscoit by Keats-Rohan). The former was dead by 1142, while the latter is perhaps most famous for founding the abbey of La Lucerne d'Outremer, which he established in 1143 with the 'council and assent' (consilio et assensu) of his surviving

118. Chantorre, dép. Manche, cant. Sartilly, c. Bacilly; Bibl. mun. Avranches, ms 206, fol. 34v35. This land was first given to the cathedral by William II in $1035 \mathrm{x} 1060$; PIgEon, Le diocèse d'Avranches..., II, p. 668.

119. For the dates of the other Norman chapters, see SPEAR, The personnel..., p. 34, 101, 136, 172, 200 and 275 .

120. Richard de Subligny died in 1153. If he died a man of seventy, and was thirty when he became dean, then the deanship was founded in 1113. Of course, the younger that de Subligny died the later in the twelfth century the deanship was founded, the latest date being 1134. There was another dean before Richard, called Urson, but it seems he was a rural dean; SPEAR, The personnel..., p. 7.

121. Members of the de Subligny family, or their relatives, appear in some ten charters in the cartulary; Bibl. mun. d'Avranches, ms 206, fols. 2v, 7v, 8v-9, 15-v, 17-v, 18-v, 21-v, 33v-34v.

122. Pigeon, Le diocèse d'Avranches..., II, p. 341, 407.

123. The name was rendered Othuerus by Orderic ( $O V$, vi, p. 304), but the author of the 'E' version of the Anglo-Saxon Chronicle used the form Ottuel; Dumville, David and Keynes, Simon (ed.), The Anglo-Saxon chronicle : a collaborative edition, Cambridge, D. S. Brewer, 200o, vol. viII, p. 121.

124. Nicolas-Méry, David, "Le 'Grand Doyenné’ à Avranches, résidence urbaine des seigneurs de Subligny”, Revue de l'Avranchin et du pays de Granville, 81, 2004, p. 135-171, at p. 152-153.

125. Subligny, dép. Manche, cant. La Haye-Pesnel.

126. Pontorson, dép. Manche, chef-lieu de cant.

127. Saint-James, dép. Manche, chef-lieu de cant.; Keats-Rohan, Domesday descendants..., p. 725726. For an excellent genealogy of the family, see Power, Daniel, The Norman frontier in the twelfth and early thirteenth centuries, Cambridge, Cambridge University Press, 2004, p. 518. 
brother ${ }^{128}$. Richard was also a kinsman (cognatus) of Richard de la Mouche, who was elected abbot of Mont-Saint-Michel at the insistence (ad instantiam) of the bishop of Avranches in $1152^{129}$.

Unfortunately, the monks did not inform Henry of Anjou of the election. The new duke of Normandy was incensed at the decision, and immediately ordered de la Mouche removed and replaced with Robert Hardy, the cellerarius of Fécamp. Richard de la Mouche then appealed to the pope, who on 7 July 1152, wrote to the bishop of Avranches ordering him to bless de la Mouche as abbot ${ }^{130}$. The ceremony that followed in Avranches cathedral did little to resolve the problem, however, and all three parties (de Subligny, de la Mouche and Hardy) eventually travelled to Rome to petition the pope in person. Eugenius III again decided in favour of de la Mouche, threatening a clash with Henry, but the situation was resolved when all three men died on their return from Italy ${ }^{131}$. The exact cause of Henry's ire is unknown. He undoubtedly wanted to maintain tight control over ecclesiastical appointments in the duchy, but the monks may have expected some leniency given their unwavering support of the duke during the civil war ${ }^{132}$. Whether the de Subligny had opposed the Angevin presence in Normandy is unknown. Their increasing dominance of ecclesiastical matters in the region must have troubled Henry, however, for not only were the bishop of Avranches and abbot of Mont-Saint-Michel members of the same family, but Hugh de la Mouche, who succeeded de Subligny as dean, and William Hayr, the archdeacon, were also related to both men ${ }^{133}$. Their presence in the city was further reinforced by Hasculf, who built an imposing urban dwelling close to the cathedral, which was later known as the "Grand Doyenné" ${ }^{134}$. Henry may simply have wanted, therefore, to prevent the domination of every key ecclesiastical post by a single family whose presence in the region already represented "une véritable colonne vertébrale" ${ }^{135}$.

128. Gallia Christiana, XI, Instrumenta, col. 113. Arthur Du Monstier held that the abbey had originally been established during the episcopate of Richard de Beaufou, and that he confirmed the abbey's foundation and dedicated it to the Holy Trinity; Du Monstier, Arthur (ed.), Neustria pia, Rouen, 1663, p. 793, 795. A charter in Dubosc's cartulary, which was edited from an ancienne copie sur papier, confirms the role of de Beaufou, although this document was destroyed in 1944; Dubosc, Cartulaire de l'abbaye de la Lucerne..., nº I, p. 1.

129. Spear, The personnel..., p. 4

130. De abbatibus montis sancti Michaelis in periculo maris, Migne, PL, CCII, col. 1327.

131. According to Desroches, Richard de Subligny was buried at Sequellammelle; Desroches, "Annales religieuses...", I, p. 430.

132. This is certainly the logic applied by one scholar to the unsuccessful election of Abbot Geoffrey (d. January 1151), which had preceded that of de la Mouche; Dufief, André, "La vie monastique au Mont Saint-Michel pendant le XII e siècle (1085-1186)”, Millénaire monastique du Mont SaintMichel, Jean LAporte et al. (éd.), 5 vol., Paris, Lethielleux, 1967-1971, I, p. 81-126, at p. 99.

133. Spear, The personnel..., p. 7, 9.

134. Nicolas-Méry, “Le 'Grand Doyenné'...”, p. 151-163. It should be noted, however, that some of the arguments in this paper rely on the mistaken belief that the de Subligny were descended from the earls of Chester.

135. Ibidem, p. 155 
The domination of ecclesiastical affairs by the de Subligny may have been problematic for the duke, but for the cathedral it offered the best means by which the deanship could be established, ensured and enriched. The repeated issuing of confirmations for the dean's possessions suggests that these benefices needed constant safeguarding. The principal benefice of the dean's prebend was, of course, the church at Vains with its cemetery ${ }^{136}$. The church was first given to the bishop of Avranches by William II at some time between 1035 and $106 \mathrm{O}^{137}$. Other religious establishments with possessions in Vains were constantly engaged in disputes over their property with both secular and religious authorities. Mont-Saint-Michel fought for over half a century with local landowners over their possession of the mill at Vains ${ }^{138}$, while Saint-Étienne de Caen, which had established the priory of Saint-Léonard using land donated by William II ${ }^{139}$, was involved in disputes with John, bishop of Lisieux (1107-1141), and Roger de Mandeville regarding water within the town ${ }^{140}$. Not only was Richard de Subligny able to rely on his brother to protect the dean's possessions (issuing charters long after the bishop's death), but he could also encourage him to enrich them. By 1412, the church at Vains brought in revenue of 17 shillings for the chapter (the third highest earning benefice in the deanship of Genêts) ${ }^{141}$, and it was still in possession of the dean in $1755^{142}$.

The other benefices that Turgis added to the prebend were no less significant than those at Vains. Unfortunately, the evidence given by the charters in this regard is inconsistent. We know that the tithes of three vavassors located in Vains formed part of the prebend, but while the first confirmation of Hugh of Amiens gives their names as William, Roger and Girard, the confirmation of Richard de Subligny replaces William with Uibert. Both these confirmations agree that the abbot of Mont-Saint-Michel owed the dean a grey pilch, but information about the next donation is confused. The acts read as follows:

..., decima de propriis vineis episcopi de campo Bostri. In manerio sancti Philiberti. Decima de molendinis de Livet et de Accurso, et de Tolwio, et decima nundine, et decima census manerii. (Hugh of Amiens confirmation, fol. $9 r$, Appendix $n^{\circ}{ }_{1}$ )

..., decima de propriis decimis episcopi de campo Botri in manerio sancti Philiberti. Decima de molendinis de Livet, et de Accurso et de Tolweio, et decima nundine, et decima census manerii. (Richard de Subligny confirmation, fol. 34 r, Appendix $n^{\circ}{ }_{3}$ )

136. For a brief survey of the various medieval ecclesiastical benefices located in Vains, see LEMETAYER, Gilbert, "Fiefs, aînesses et dimes à Vains", Revue de l'Avranchin et du Pays de Granville, 85, 1998, p. 137-147.

137. Pigeon, Le diocèse d'Avranches..., II, p. 667.

138. Fauroux, Recueil..., no ${ }^{\circ} 48$; Bates, Regesta..., n ${ }^{\circ}$ 214; Keats-Rohan, The cartulary ..., no 6 .

139. Robert Curthose confirmed this grant of land, which was made by his father on his deathbed (i.e. 9 September 1087); Haskins, Norman Institutions, Appendix E, $\mathrm{n}^{\circ} 1, \mathrm{p} .285$. The history of the priory, and a previously unedited version of this charter, are discussed in Bouvris, "Aux origines...", p. 3-21, 67-90. The charter is edited on p. 82-85.

140. Johnson and Cronne, Regesta..., II, $\mathrm{n}^{\circ} 1672$.

141. Longnon, Auguste, Pouillés de la province de Rouen, Paris, Imprimerie nationale, 1903, p. 155.

142. Le Héricher, Avranchin monumental..., I, p. 179. 
David Spear held that Turgis gave the tithes of the vineyards of campo Botri, which he located at Vains ${ }^{143}$. Desroches, however, from whom Spear worked, did not assign the vineyards to any particular location (see above). The first charter does not stipulate where these vineyards were, while the second charter clearly indicates that not only did Turgis grant tithes rather than vineyards, but that this benefice was in the manor of Saint-Philbert-sur-Risle. The rather clumsy formula employed by de Subligny's charter ("the tithes of his own [i.e. the bishop's] tithes") perhaps suggests a scribal error, but nothing is certain without originals to prove otherwise. Unfortunately, it has not been possible to confirm the presence of a campo Botri, which Desroches styled Champ-du-Bout, in either Vains or Saint-Philbert ${ }^{144}$, although a later agreement between Hasculf and the abbot of Savigny, which stipulated that his monks would lead Hasculf's mule as far as campo Botri, probably suggests that it was in the former ${ }^{145}$. Regardless, the decision to sustain the deanship with donations from the manor of SaintPhilbert is itself significant. The manor had first been given to the cathedral by Bishop John in $1066^{146}$. It was one of only a handful of eleventh- and twelfthcentury cathedral possessions located outside the diocese, and was highly valued ${ }^{147}$. John was remembered fondly in the cartulary for his endowment ${ }^{148}$, while his successor secured confirmation of the donation from William de Breteuil by paying him 100 livres in Rouen money ${ }^{149}$. Two of the three mills in the manor (Livet, Accurso and Tolwio) from which the dean claimed tithes were identified by Michèle Lebrun as Livet-sur-Authou and Touvée or Touvoie, which

143. Spear, The personnel..., p. 6.

144. There is a commune called Champ-du-Boult, dép. Calvados, cant. Saint-Sever-Calvados, but it seems unlikely that this is the place in question. There is also no place called Champ-du-Bout listed in any of the topographical dictionaries for the department of the Eure or the Manche, either under the entries for place-names beginning with 'Champ' or under the entries for Saint-Philbert and Vains; Blosseville, Ernest Poret de (éd.), Dictionnaire topographique du département de l'Eure: comprenant les noms de lieu anciens et modernes, Paris, Imprimerie nationale, 1877, p. 5051, 204; LePrévost, Auguste (éd.), Mémoires et notes... pour servir à l'histoire du département de l'Eure, 3 vol., Évreux, Auguste Hérissey, 1862-1869, I, p. 484-486; III, p. 183-185; CHARPILlon and Anatole Caresme (éd.), Dictionnaire historique de toutes les communes du département de l'Eure, 2 vol., Les Andelys, Delcroix, 1868-1879, I, p. 704; II, p. 842-844. Cf. BeAurepaire, François de (éd.), Les noms des communes et anciennes paroisses de l'Eure, Paris, Picard, 1981, p. 186; ID, Les noms des communes et anciennes paroisses de la Manche, Paris, Picard, 1986, p. 228. The name also does not survive among any of the hamlets in modern-day Vains or Saint-Philbert; INSEE, Nomenclature de la Manche..., $2^{\mathrm{e}}$ partie, p. 158; Ibidem, Nomenclature des hameaux : écarts et lieux-dits du département de l'Eure, Rouen, INSEE, 1955, $2^{\mathrm{e}}$ partie, p. 80.

145. BnF, ms lat. n. a. 1022, p. $140\left(n^{\circ} 147\right)$.

146. Fauroux, Recueil..., $\mathrm{n}^{\circ} 229$.

147. The cathedral's other significant extra-diocesan holding was in Portchester (Hampshire), which was first given to them by Hugh I, earl of Chester; Peltzer, Jörg, "Portchester, les évêques d'Avranches et les Hommet (1100-1230)", Annales de Normandie, 56 année, 2006, n 5, p. 463482. There were also three minor possessions in the diocese of Coutances; LEBRUN, Le temporel..., p. 75.

148. "Ita que in anniuersario felicis memorie Iohannis quondam Abrincensi episcopi qui dedit manerium sancti Philiberti ecclesie Abrincensi percipient xx solidos Turensis”; Bibl. mun. Avranches, $\mathrm{ms} 206, \mathrm{f}^{\circ} 10 \mathrm{v}$.

149. Pigeon, Le diocèse d'Avranches..., II, p. 661. 
was situated at Pont-Authou ${ }^{150}$. Combined with the tithes of the market, and the tithes of the revenue of the manor, these benefices must have brought substantial revenue to the dean and his chapter. Given its value, it is strange that among the numerous confirmations issued by other bishops for the deanship, there is not one from the bishop of Évreux, in whose diocese the manor of SaintPhilbert lay.

Despite their value, it appears that only one of the benefices was ever contested. In 1213, Hugh de Morville, bishop of Coutances, arbitrated a dispute between the abbot of Mont-Saint-Michel and Nicholas de Aquila, dean of Avranches, over the grey pilch that the abbot owed annually to the dean as part of his prebend ${ }^{151}$. Relations between the abbey and cathedral were rarely easy. During the century long vacancy that had occurred in the episcopal seat during the ninth and tenth centuries, Mont-Saint-Michel had established itself as the premier ecclesiastical institution in the region. Only when Bishop John issued his famous conventio in 1061 was episcopal authority reasserted over the abbey in the eleventh century ${ }^{152}$. The twelfth century was one of two halves for the abbey. During the first half it was plagued by successive woes, but by the end of the second it had been fully regenerated by Robert de Torigini ${ }^{153}$. Despite this renaissance, during the thirteenth century the bishops of Avranches began increasingly to exercise their authority in the diocese, which was met with resistance at Mont-Saint-Michel ${ }^{154}$. The opening years of the century were unhappy ones for the abbey, however, and under Abbot Jordan (1191-1212) the religious life, which had been seriously disrupted by a fire in 1204 , continued to be neglected. The situation became so bad that four years later the pope, at the urging of the bishop of Avranches, had ordered the bishop of Lisieux and abbot of Savigny to investigate. This apparently had little impact, and on 5 September 1210 the pope ordered the same two men, plus Hugh, bishop of Coutances, to revisit the abbey, which they did on 30 May $1211^{155}$. An agreement was made placing the monastic chapter in charge of abbey life, which it duly governed until Jordan's death on 6 August 1212. Relations between the bishop of Avranches and the abbey remained sour, however, and when William (IV) Bureau (1210-1236) attempted to oversee the election of Jordan's successor he was refused entry to the abbey. The next abbot, Rodulf des Isles (1212-1229), energetically pursued the reconstruction of his abbey, and it is in the context of this renewal that our charters must be placed. Turgis, undoubtedly well aware of the subordinate role his predecessors were often forced to play by the abbey, had perhaps deliberately involved it in the sustenance of the new deanship, but it was a role that by 1213 it either would

150. Lebrun, "Le temporel...", p. 75. It is possible that Accurso was in the same place as Touvoie.

151. Bibl. mun. Avranches, ms 206, $\mathrm{f}^{\circ} 35-\mathrm{v}$.

152. Lemarignier, Étude..., p. 158-160; Allen, “John of Ivry...”, (forthcoming).

153. Dufief, "La vie monastique...", p. 101-119.

154. For what follows, see Chazelas, Jean, "La vie monastique au Mont Saint-Michel au XIII ${ }^{e}$ siècle", Millénaire monastique..., I, p. 127-150, esp. p. 130-131, 140-144.

155. Both charters dealing with dispute make reference to the authority granted by Innocent III to the bishop of Coutances. 
not, or could not, afford to play. The abbey was not entirely successful in its case, however, since the bishop of Coutances ordered that it pay six livres annually (nine in the money of Tours on the Octave of Easter) in lieu of the pilch ${ }^{156}$.

The legacy of Turgis' decision to found the deanship was therefore long felt. It did not take long for the chapter to recognise its debt to him, and the cartulary charters testify to the fondness with which Turgis was soon remembered. But perhaps the greater debt was owed by the de Subligny, for as much as the family had helped establish the deanship, so the deanship had also helped establish the family. For three heady years in the early 1150s they controlled every major ecclesiastical post in the region, while the secular branch also continued to expand. Within two generations members of the family were favourites in the court of Henry II, while the son of Richard de Subligny's nephew eventually became count of Dol ${ }^{157}$. If evidence exists to suggest that Richard was aware of the debt he owed his predecessor, it is perhaps to be found in his charter concerning the deanship, where Turgis is for the first (and only) time associated with sanctity ${ }^{158}$.

\section{Conclusion}

These five charters are of the utmost importance to our knowledge of the deanship. While we can reconstruct the holdings of the other deans of the province of Rouen based on later pouillés, it is only for Avranches that we can name for certain the benefices belonging to the dean at the moment of its foundation. The number and scope of the confirmations for the deanship also clearly demonstrates that the chapter was keen to safeguard one of its most important assets. It turned not only to its metropolitan for protection, but also to the abbots and bishops of neighbouring dioceses. Perhaps most interesting of these is that issued by a John, bishop of Dol, which appears in the first charter of the archbishop of Rouen. As has just been noted above, by the late twelfth century members of the de Subligny family had been made counts of Dol. Interestingly, John (V) de la Mouche, whose toponym suggests he may have been a kinsman of the de Subligny, was bishop of Dol between c. 1190 and $1199{ }^{159}$. However, since the Dol confirmation follows that of Hugh de Morville, bishop of Coutances, it is more likely

156. "Lis in hunc modus amicabiliter conquierunt, videlicet que quam uis antea pro dicta pellicia vi libras usualis monete quibusdam decanus Abrincensis predicti abbas et conventus predicto decano suisque successoribus infra octabas pache ix libras Turonensis, vel usualis monete pro soluent libere et quiete imposterum annuatim"; Bibl. mun. Avranches, ms 206, $\mathrm{f}^{\circ} 35$.

157. Hasculf, son of John de Subligny, was given as husband to the heiress Isledis, daughter of John II of Dol-Combour; Keats-Rohan, Domesday descendants..., p. 726.

158. The phrase "ab illustri et pie recordationis episcopo Turgisio" in the charter of Hugh of Amiens becomes "ab illustri et sancte recordationis episcopo Turgigio [sic]" in that of Richard de Subligny.

159. Gallia Christiana, xIv, col. 1052. 
that the bishop was John (VI) de Lysenach (1203-1231) ${ }^{160}$. He occupied his diocese at about the same time as Hugh, and was not unfamiliar with affairs in the diocese of Avranches ${ }^{161}$. Indeed, in the year before Hugh de Morville ascended to the episcopate ${ }^{162}$, John worked with him to broker a conventio between the abbey of La Lucerne and the chapter of Avranches concerning the abbey's use of revenues from vacant prebends ${ }^{163}$. This benefice had originally been granted to La Lucerne by Achard, bishop of Avranches (1161-1170). Although the chapter claimed to extend these rights willingly it was undoubtedly a costly benefice to maintain. Perhaps in the following year (1208) John de Lysenach was persuaded by the bishop of Coutances, himself a former servant of the bishops of Dol, to issue a confirmation of the deanship by way of recompense.

Of course, without originals, and a contemporary narrative history of the diocese, many issues concerning the deanship remain unresolved. We would still like to know when exactly the position was established (was it perhaps associated with the consecration of the new cathedral in 1121?), whether Turgis himself was in any way related to the de Subligny, and, of course, the exact circumstances behind each confirmation. Though as frustrating as these silences are, they also serve to remind us of the unique nature of cartulary texts, and the caution with which scholars of evidence-starved dioceses such as Avranches must use these resources. David Bates, Katherine Keats-Rohan and Pierre Chastang, among others, have all recently recalled that the compilers of cartularies were never mere copiers of existing texts, and that behind the creation of each codex, and the charters selected for inclusion, lay a specific set of circumstances ${ }^{164}$. Ironically, in works whose primary function was the memorialisation of key benefactors and benefices, the nature of medieval archival culture is often so far removed from current practices that the ability of the cartulary to successfully communicate the memory of a particular act often decreases, rather than increases, with time. The cartulary of Avranches cathedral is no different. Even the medieval scribes responsible for its creation managed to create ambiguity for later generations through their own transcriptional errors (was one of the vavassors named

160. The origins of this cognomen are unknown. It is rendered in many different ways, including Lysenech, Lesenech, Lizannet, Lisanet and Lesonet.

161. Gallia Christiana, xIv, cols. 1052-1053.

162. Hugh was formerly archdeacon of Coutances. For his career, where he sometimes appears as Mag. Hugh Nereth, see Spear, The personnel..., p. 100-101.

163. Gallia Christiana, xI, Instrumenta, col. 115-116.

164. BAtes, David, "Charters and historians of Britain and Ireland: problems and possibilities", in Charters and Charter Scholarship in Britain and Ireland, Judith GREEN and Marie-Therese FLANAGAN (ed.), Houndmills, Palgrave MacMillan, 2005, p. 1-14, esp. p. 11-12; KeAts-Rohan, The cartulary..., p. 1-4; Chastang, Pierre, "Cartulaires, cartularisation et scriptularité médiévale: la structuration d'un nouveau champ de recherche", Cahiers de civilisation médiévale, 49, 2006, p. 21-32, esp. 27-30; ID, "Entre histoire et reconstruction des origines. Les actes anciens (IX ${ }^{\mathrm{e}}$ siècle) des cartulaires de Gellone", in Saint-Guilhem-le-Désert dans l'Europe du haut Moyen Âge, Claudie Duhamel-Amado and Xavier Barral i Altet (éd.), Montpellier, 2000, p. 65-74; ID, Lire, écrire, transcrire. Le travail des rédacteurs de cartulaires en Bas-Languedoc (XI'-XIII ${ }^{e}$ siècle), Paris, CTHS (CTHS Histoire, 2), 2001. 
William or Uibert, for example), and such uncertainties could even affect the memorialisation of those individuals principally involved in the deanship's foundation. Most famously, when Émile-Auber Pigeon came to discuss its creation in his magisterial survey of the diocese's history, the cartulary texts had proved so confusing that he claimed the deanship had been founded not by Turgis, but instead by Richard de Beaufou ${ }^{165}$.

\section{Bibliography}

Allen, Richard, “'A proud and headstrong man': John of Ivry, bishop of Avranches and archbishop of Rouen, 1067-1079", Historical Research, (forthcoming).

BAtes, David, (ed.), Regesta regum Anglo-Normannorum: the Acta of William I, 10661087, Oxford, Clarendon Press, 1998, xxxviii-1153 p.

BAUDUIN, Pierre, La première Normandie ( $X^{e}-X I^{e}$ siècles): sur les frontières de la haute Normandie, Caen, Presses universitaires de Caen, 2004 ( $2^{\mathrm{e}}$ édition 2006), $469 \mathrm{p}$.

Bouet, Pierre et Dosdat, Monique, "Les évêques normands de 985 à 1150", in Les évêques normands du XI siècle, Pierre Bouet et François Neveux (dir.), Caen, Presses universitaires de Caen, 1996, p. 19-37.

Bourrienne, Valentin (éd.), Antiquus cartularius ecclesice Baiocensis (livre noir), 2 vol., Société de l'histoire de Normandie, 1902-1903, cxix-333 p.

Charpillon and Anatole Caresme (éd.), Dictionnaire historique de toutes les communes du département de l'Eure, 2 vol., Les Andelys, Delcroix, 1868-1879, vii$960 \mathrm{p}$. et iv-1010 p.

Chédeville, André and Guillotel, Hubert, La Bretagne des saints et des rois: $V^{e}$ $X^{e}$ siècle, Rennes, Ouest-France, 1984, 423 p.

Chibnall, Marjorie (éd.), The Ecclesiastical History of Orderic Vitalis, 6 vol., Oxford, Clarendon Press, 1969-1980, xvi-386 p., xliii-409 p., xxviii-408 p., xliii-393 p., xix413 p. et xxvii-611 p.

Desroches, Jean-Jacques, “Annales religieuses de l'Avranchin", 3 pts., Mémoires de la Société des antiquaires de Normandie, 14, 1844, p. 395-408 and 17, 1850, p.1190, 321-387.

Desroches, Jean-Jacques, "Sur les paroisses du Mont-Saint-Michel”, Mémoires de la Société des antiquaires de Normandie, 14, 1844, p. 37-128.

Dubosc, François-N. (éd.), Cartulaire de l'abbaye de la Lucerne, Saint-Lô, 1878, vi-253 p.

Fauroux, Marie (éd.), Recueil des actes des ducs de Normandie, 911-1066, Mémoires de la Société des antiquaires de Normandie, 36, 1961, 560 p.

Fontanel, Julie, "La réorganisation religieuse sous Guillaume le Conquérant: le cas de l'église de Coutances", Revue de l'Avranchin et du Pays de Granville, 77, 200o, p. 189-208.

FournéE, Jean, "Notes sur un évêque d'Avranches au XII siècle: Richard de Beaufou (1134-1143)", Revue de l'Avranchin et du pays de Granville, 33, 1946, p. 359-364. 
Gallia Christiana in provincias ecclesiasticas distributa, 16 vol., Paris, Victor Palme, 1715-1865.

Gazeau, Véronique, Normannia monastica. Princes normands et abbés bénédictins ( $X^{e}$-XII siècle), 2 vol., Publications du CRAHM, Brepols, Turnhout, 2008, xiii492 p. et vi-403 p.

Haskins, Charles H., Norman institutions, Cambridge, Mass., Harvard University Press, 1918, vi-377 p.

Keats-Rohan, Katherine S.B. (ed.), The cartulary of the abbey of Mont-Saint-Michel, Donington, Shaun Tyas, 2006, xiii-319 p.

Keats-Rohan, Katherine S.B. (ed.), Domesday people: a prosopography of persons occurring in English documents 1066-1166. 1, Domesday book, Woodbridge, Boydell Press, 1999, vi, $563 \mathrm{p}$.

Keats-Rohan, Katherine S.B. (ed.), Domesday descendants: a prosopography of persons occurring in English documents 1066-1166, II, Pipe rolls to Cartae baronum, Woodbridge, Boydell Press, 2002, 1169 p.

Keats-Rohan, Katherine S.B., "William I and the Breton contingent in the non-Norman Conquest 1060-1087", Anglo-Norman Studies, 13, 1990, p. 157-172.

Keats-Rohan, Katherine S.B., "The Bretons and Normans of England 1066-1154: the family, the fief and the feudal monarchy", Nottingham Medieval Studies, 36, 1992, p. $42-78$.

Lauer, Philippe (éd.), Nithard, Histoire des fils de Louis de Pieux, Paris, Les Belles Lettres, 1926, xx, $172 \mathrm{p}$.

LAPorte, Jean (éd.), Annales fontanellenses priores, Mélanges de la Société de l'Histoire de Normandie, 15, 1951, p. 65-90.

L.C., "Turgis, évêque d'Avranches (1094-1134)", Revue de l'Avranchin et du pays de Granville, 49, 1972, p. 71-73.

Le Héricher, Edouard, Avranchin monumental et historique, 3 vol., Avranches, Tostain, 1845-1865, xvi-653 p., 750 p. et 226 p.

LePrévost, Auguste (éd.), Mémoires et notes... pour servir à l'histoire du département de l'Eure, 3 vol., Évreux, Auguste Hérissey, 1862-1869, xxxii-576 p., 632 p. et 316 p.

Lebreton, Charles, "L'école d'Avranches au XI" siècle sous Lanfranc et saint Anselme", Mémoires de la Société archéologique d’Avranches, 6, 1873, p. 493-510.

Lebrun, Michèle, "Le temporel des évêques d'Avranches du XI ${ }^{\mathrm{e}}$ au XIV $\mathrm{X}^{\mathrm{e}}$ siècle", Diplôme d'Études Supérieures d'histoire, université de Caen, s.d., 168 p. (dactyl.).

Lebrun, Michèle, "Le temporel des évêques d'Avranches du XI au XIII siècle", Revue de l'Avranchin et du Pays de Granville, 42, 1965, p. 58-80.

LEMARIGNIER, Jean-François, Étude sur les privilèges d'exemption et de juridiction ecclésiastique des abbayes normandes depuis les origines jusqu'en 1140, Paris, A. Picard, 1937, xxxiii-331 p.

Les évêques normands du XI siècle, Pierre Bouet et François Neveux (dir.), Caen, Presses universitaires de Caen, 1996, 330 p.

Levalet, Daniel, "La cathédrale Saint-André et les origines chrétiennes d'Avranches", Archéologie médiévale, 12, 1982, p. 107-153. 
Mabillon, Jean (éd.), Annales ordinis Sancti Benedicti occidentalium monachorum patriarchae, 6 vols., Luca, Leonardi Venturini, 1739-1745.

Masselin, Marie-Joseph, "Études sur les étymologies des noms de lieux et des noms de famille dans l'Avranchin: Table de ces étymologies par ordre alphabétique", Mémoires de la Société archéologique d'Avranches, 12, 1894-1895, p. 127-227.

Nicolas-Méry, David, “Le 'Grand Doyenné’ à Avranches, résidence urbaine des seigneurs de Subligny”, Revue de l’Avranchin et du pays de Granville, 81, 2004, p. 135171.

Peltzer, Jörg, "Portchester, les évêques d'Avranches et les Hommet (1100-1230)", Annales de Normandie, 56e année, 2006, $\mathrm{n}^{\circ}$ 5, p. 463-482.

Pigeon, Émile-Auber, Le diocèse d'Avranches, sa topographie, ses origines, ses évêques, sa cathédrale, ses églises, ses comtes et ses châteaux, 2 vol., Coutances, Salettes, $1888,714 \mathrm{p}$.

Power, Daniel, The Norman frontier in the twelfth and early thirteenth centuries, Cambridge, Cambridge University Press, 2004, xxi-634 p.

Smith, Julia, Province and empire: Brittany and the Carolingians, Cambridge, Cambridge University Press, 1992, xx-237 p.

SPEAR, David, The personnel of the Norman cathedrals during the ducal period, 911-1204, London, Institute of Historical Research (coll. Fasti Ecclesiae Anglicanae. 10661300), 2006, $\mathrm{xl}-334 \mathrm{p}$.

VAn Torhoudt, Eric, 'Les sièges du pouvoir des Néel, vicomtes dans le Cotentin', in Les lieux de pouvoir au Moyen Âge en Normandie et sur ses marges, Anne-Marie Flambard Héricher (dir.), Caen, Publications du CRAHM, 2006, p. 7-35.

Waldman, Thomas G., "Hugh 'of Amiens', archbishop of Rouen, 1130-1164”, unpublished D. Phil thesis, University of Oxford, 1971, 648 p. (dactyl.).

\section{Appendix I}

\section{1 - First confirmation by Hugh of Amiens, archbishop of Rouen,} of the foundation of the deanship of Avranches

A. Original lost.

B. Bibl. mun. d'Avranches, ms 206, $\mathrm{f}^{\circ} 8 \mathrm{v}-9$.

Ptd. Lebrun, "Le temporel [diplôme]...", p. 14; Le Héricher, Avranchin monumental..., I, p. 178-179 (partial transcription).

Ind. Desroches, "Annales religieuses...", I, p. 428-429; Desroches, "Sur les paroisses...", p. 49; LE Héricher, Avranchin monumental..., i, p. 178-179; SPEAR, The personnel..., p. 6.

Note. This charter is dated by the episcopate of Richard de Beaufou. Since the confirmations of the bishops of Coutances and Dol that follow were probably made at the same time, they are dated from 1203 x 1231, i.e. the episcopal dates of John (VI) de Lysenach. 
Ordinatio super decanatu ecclesie Abrincensis

Hugo, dei gratia Rothomagensis archiepiscopus, karissimis filiis, Ricardo episcopo ${ }^{166}$, Ricardo decano ${ }^{167}$, archidiaconis, et capitulo, Abrincensis, ecclesie salutem graciam et benedictionem. Quod ad dignitatem et incrementum sancte Matris ecclesie pertinere dignoscitur a pastoribus et rectoribus ejus devota deus caritate suscipi, et effectum mancipari, verumptamen qui a pie recordationis episcopo nostro Turgisio ${ }^{168}$ provide statutum est, et post communi assensu capituli nostri, litteris et attestatione patris nostri, Ricardi de decanatu ecclesie nostre canonice confirmatum auctore metropolitana decernimus annuere, et imperpetuum ecclesie nostre et nobis firrmus corroborare. Sicut enim a prefatis episcopis hoc ipsum confirmatum et cartis corroboratum est. Ista percipimus nostra quam prominemus auctore in posterum observari, et nulla varietate violari, hec igitur ecclesie nostre et nobis sit pax et reliqua. Ricardus dei gratia Abrincensis episcopus successoribus suis episcopis in perpetuum. Nos itaque Ricardus de Suligneio ingenuo siquidem et magne frugillitatis ${ }^{169}$ nec minoris spe miro ${ }^{170}$ decanatum in honorem ecclesie nostre ab illustri et pie recordationis episcopo Turgisio, cui de auctore suocessimus ${ }^{171}$ institutum concessimus et presentis nostri pagina scripti, assensu capituli nostri firma stabilitate confirmamus. Ex ut hujus decanatus institutio firrmus stet inperpetuum, nostri sigilli impressione communimus, et episcopali auctoritate roboramus. Si quis autem hanc nostri predecessoris et caetera. Sunt autem decanatui huic aplicata: ecclesia de Veim ${ }^{172}$ et census cimiterii, et decime trium vavassaorum in Veim, scilicet, Willelmi et Rogeri, et filiorum Gyrardi, et masura cujusdam Girardi ${ }^{173}$, cum decima. De abbate Montis: una pellicia grissata ad mensuram suppellicii ${ }^{174}$, decima de propriis vineis episcopi de campo Bostri. In manerio sancti Philiberti ${ }^{175}$. Decima de molendinis de Livet ${ }^{176}$ et de Accurso ${ }^{177}$, et de Tolwio ${ }^{178}$, et decima nundine, et decima census manerii. Quibus ipse Ricardus adjecit decimam de Choeio ${ }^{179}$ que

166. Richard de Beaufou, bishop of Avranches, 1134-1143.

167. Richard de Subligny, dean of Avranches, ?-1143.

168. Turgis, bishop of Avranches, 1094-1134.

169. Sic B, corr. frugalitatis.

170. Sic B, corr. viro.

171. Sic B, corr. successimus.

172. Vains, dép. Manche, cant. Avranches.

173. These three individuals cannot be identified any more precisely.

174. Sic B, corr. superlicii.

175. Saint-Philbert-sur-Risle, dép. Eure, cant. Montfort-sur-Risle.

176. Livet-sur-Authou, dép. Eure, cant. Brionne.

177. An unidentified place-name, probably located within Pont-Authou, dép. Eure, cant. Montfortsur-Risle.

178. Probably to be identified with the place Touvée or Touvoie, which was situated within PontAuthou.

179. Probably to be identified with the land called Toeio /Toi (texts $n^{\circ} 2$ and 5 ), which was located within Subligny, dép. Manche, cant. La Haye-Pesnel. 
est de feodo fratris sui cum ejus concessione. + Ego, Ricardus episcopus propria manu, scripsi. Ego, Hugo, dei permissione Constanciensis episcopus ${ }^{180}$, auditis super huic autenticis instrumentis Abrincensi ecclesie et diligenter inspectis, que in presenti pagina verbo ad verbum fideliter transcripta sunt presentem paginam sigilli mei testimonio dignum duxi communire. Similiter nos, Johannes episcopus ${ }^{181}$ et capitulum Dolensis ecclesie ipsa originalia cum sigillis, verbo ad verbum fideliter hic transcripta diligenter inspeximus, et auduimus. Ad testimonium hujus veritatis sigilla nostra facientes apponi.

\section{2 - Confirmation of the foundation of the deanship of Avranches by Richard de Subligny, bishop of Avranches}

A. Original lost.

B. Bibl. mun. d'Avranches, ms 206, fol. 33V-34.

Ptd. Lebrun, "Le temporel [diplôme]...", p. 61.

Note. This charter is dated by the episcopate of Richard de Subligny.

$$
1143 \times 1153
$$

$B$

Confirmatio Hugonis archiepiscopus Rothomagensis super decinatu ecclesie Abrincensis ${ }^{182}$

Ricardus, miseratione divina Abrincensis episcopus, successoribus suis imperpetuum episcopis, sancta et universalis mater ecclesia, bone spei filios brachiis pie dilectionis arcius amplectitur et diligencius in gremio suo fouet et ubiuis de proprio lactat ubere. Nos itaque Ricardus de Suligneio ingenuo, siquidem et magne frugalitatis nec minoris spei viro, decanatus in honorem nostre ecclesie ab illustri et sancte recordationis episcopo Turgigio ${ }^{183}$, cui deo auctore successimus institutum, concessimus et presentis nostri pagina scripti, assensu capituli nostri firma stabilitate confirmamus, et ut huic decanatus institutio firmus stet imperpetuum nostri sigilli impressione communimus, et episcopali auctoritate coroboramus. Si quis vero hanc predecessoris nostri et nostram institutionem ausu temerario scienter infringere seu diminuere temptauerit, canonice conmonitus nisi correxerit bonorum apostolorum Petri et Pauli atque Andrae indignationem incurrat, et anathema maranatha si perseverauerit sustineat. Conservantibus autem pacem datis, et ad augmentum bonorum conferentibus sit pax, et felicitas perpetua amen. Sunt autem hec decanatui aplicata. Ecclesiam de Veim, scilicet Viberti et Rogeri, et filiorum Girardi, et masura ejusdem Gir-

180. Hugh de Morville, bishop of Coutances, 1208-1238.

181. John (VI) de Lysenach, bishop of Dol, 1203-1231.

182. Sic $\mathrm{B}$, this rubrication belongs with text $\mathrm{n}^{\circ} 3$. For the identification of the majority of place and personal names within this charter, see the notes for text $n^{\circ} 1$.

183. Sic B, corr. Turgio. 
ardi cum decim ${ }^{184}$, de abbate Montis una pellicia grisia ad mensuram superlicii, decima de propriis decimis episcopi de campo Botri in manerio sancti Philiberti. Decima de molendinis de Livet, et de Accurso et de Tolweio, et decima nundine, et decima census manerii. Quibus ipse Ricardus adjecit decimam de Toeio que est ex feodo fratris sui cum ejus concessione. + Ego Ricardus episcopus propria manu.

\section{3 - Second confirmation by Hugh of Amiens, archbishop of Rouen, of the foundation of the deanship of Avranches}

A. Original lost.

B. Bibl. mun. d'Avranches, ms 206, fol. 34-v.

Ptd. Lebrun, "Le temporel [diplôme]...", p. 61-62.

Ind. Gazeau, Normannia monastica..., ii, p. 89, 217, 255.

Note. This charter was most likely issued in the months following the capture of Avranches by the count of Anjou in 1142. Strictly speaking, however, it should be broadly dated $1138 \times 25$ April 1143, i.e. between the first appearance of Giles, archdeacon of Rouen, and the death of the bishop of Avranches.

$$
\begin{gathered}
\text { C. } 1142 \\
B
\end{gathered}
$$

Confirmatio R. episcopi super decanatu ecclesie Abrincensis ${ }^{185}$

Hugo, dei gratia Rothomagensis archiepiscopus, karissimis filiis suis, Ricardo episcopo, Ricardo decano, archidiaconis et capitulo Abrincensi, salutem in domino graciam et benedictionem. Quod ad dignitatem et incrementum sancte Matris ecclesie pertinere dignoscitur a pastoribus et rectoribus ejus devota de caritate suscipi, et effectui mancipari verumptamen qui a pie recordationis episcopo nostro Turgigisio ${ }^{186}$ provide statutum est, et post communi assensu capituli nostri, litteris et attestationibus patris nostri Ricardi episcopi et decanatu ecclesie nostre canonice confrimatum auctoritate metropolitana decernimus annuere, et imperpetuum ecclesie nostre et vobis firmius corroborare. Sicut enim a prefatis episcopis hoc ipsum confirmatum et cartis corroboratum est. Ita percipimus nostra quam preminemus auctore in posterum observari et nulla varietate violari. Hec igitur ecclesie nostre et vobis multa servantibus sit pax domini nostri Ihesu Christi. Amen. Quisquis vero contra hanc nostre constitutionis paginam scienter venire temptauerit, nisi pie que incepit, corrigere procurauerit, sciat se anathemati subiciendur, et gravi iactura plectandum.

Ego Hugo Rothomagensis archiepiscopus

Ego Ricardo Abrincensis episcopus 
Ego Arnulphus Lexiovensis episcopus ${ }^{187}$

Ego Waleranus decanus Rothomagensis ecclesie ${ }^{188}$

Ego Gaufridus archidiaconus ${ }^{189}$

Ego Osmundus archidiaconus ${ }^{190}$

Ego Bernardus abbas montis sancti Michaeli ${ }^{191}$

Ego Fraternus abbas sancti Audoeni ${ }^{192}$

Ego Rad. abbas de cruce sancti Leufridi ${ }^{193}$

Ego Fulbertus archidiaconus ${ }^{194}$

Ego Hugo archidiaconus ${ }^{195}$

Ego Egidius archidiaconus ${ }^{196}$

4 - Inspeximus issued by either Richard of Gloucester or Robert des Ablèges, bishop of Bayeux, of the foundation of the deanship of Avranches

A. Original lost.

B. Bibl. mun. d'Avranches, ms 206, fol. 34v.

Ptd. Lebrun, "Le temporel [diplôme]...", p. 62.

Note. The two dates assigned to this charter refer either to the episcopate of Richard of Gloucester or of Robert des Ablèges. The inspeximus of the abbot of Lessay was made at sometime between c. 1321 x c. 1337.

$1135 \times 1142$ or $1206 \times 1231$

B

Littera episcopi Baiocensis super decanatu ecclesie Abrincensis

Nos vero R. dei gratia sustinencia Baiocensis episcopus originalia predictorum, Hugonis Rothomagensis archiepiscopi, et Ricardi Abrincensis episcopi, sigillis suis munita, que hic verbo ad verbum fideliter sunt transcripta diligenter inspeximus et legimus ad testimonium et veritatem hujus veritatis sigillum nostrum facientes apponi. Similiter nos Guillemus ${ }^{197}$ decanus et capitulum Baiocensis ecclesie ipsa originalia cum sigillis verbo ad verbum fideliter hic transcripta diligenter inspeximus et adiuimus sigillum nostrum ad hujus veritatis

187. Arnulf, bishop of Lisieux, 1141-1181.

188. Waleran, dean of Rouen, c. 1137-c. 1146.

189. Geoffrey, archdeacon of Rouen, 1133-1148.

190. Osmund II, archdeacon of Rouen, 1111X1115-1158.

191. Bernard, abbot of Mont-Saint-Michel, 1131-1149.

192. Fraternus, abbot of Saint-Ouen de Rouen, after 12 June 1141 x before 1 Aug. 1142-1157.

193. Rodulf, abbot of La Croix-Saint-Leufroy, before 1143-after 1158 .

194. Fulbert III, archdeacon of Rouen, c. 1124-c. 1158.

195. Either Hugh de Fréuville, archdeacon of Rouen, c. 1138-c. 1158, or Hugh de Lingèvres, archdeacon of Avranches, 1142.

196. Giles, archdeacon of Rouen, 1138-1170.

197. Either a previously unidentified dean named William operating during the episcopate of Richard of Gloucester, bishop of Bayeux, 1135-1142, or William IV, dean of Bayeux, 1213-1226. 
testimonium apponentes. Similiter nos conventus sancti Laudi dyocesis Constanciensis ipsa originalia cum sigillis verbo ad verbum fideliter hic transcripta diligenter inspeximus et audiuimus sigillum nostrum ad hujus veritatem testimonium apponentes. Similiter nos Silvester ${ }^{198}$ abbas et conventus sancte Trinitatis Exaquii, ipsa originalia cum sigillis verbo ad verbum fideliter hic transcripta diligenter inspeximus et audiuimus sigillum capituli nostri ad hujus veritatis testimonium apponentes.

\section{5 - Confirmation of Hasculf de Subligny,} of the donation of Toi to the deanship of Avranches

\section{A. Original lost.}

B. Bibl. mun. d'Avranches, ms 206, fol. $34 \mathrm{v}$.

Ptd. Lebrun, "Le temporel [diplôme]...", p. 62.

Note. This charter must have been issued after 1162, since it refers to Rolland, dean of Avranches (who first appears on 8 April of that year), but before Hasculfs death in 1169 .

$$
1162 \times 1169
$$

B

De donatione decime de Toy

Notum sit omnibus tam presentibus quam futuris quod ego Hasculphus de Suligneio duas garbas de Toi quas Ricardus frater meus pie recordacionis episcopus habuerat dum decanus esset et post eum quod ei successit Hugo de Musca ${ }^{199}$, Rollando decano ${ }^{200}$ et omnibus decanis Abrincensis, imperpetuam elemosinam concessi et donationem meam presente capitulo super altare posui. Quam ut firmior esset sigilli mei impressione roboraui et etiam singulorum domini episcopi et capituli Abrincensi munimine roborari volui, assuerunt autem huic donationi laici plures, Ranulphus de Praeres ${ }^{201}$, Alanus de Insula, Petrus de Verduno ${ }^{202}$, Guillelmus filius Augeri et multi alii.

198. Sylvester, abbot of Lessay, c. 1321-c. 1337.

199. Hugh de la Mouche, dean of Avranches, 1143-1160.

200. Rolland, dean of Avranches, 8 April 1162-c. 1187/8.

201. Presles, dép. Calvados, cant. Vassy. Rannulf was probably the son of Matthew de Presles and his wife Beatrice, a was a tenant of the earls of Chester.

202. The land of Verdun is located in Vessey, dép. Manche, cant. Pontorson. 


\section{Appendix II}

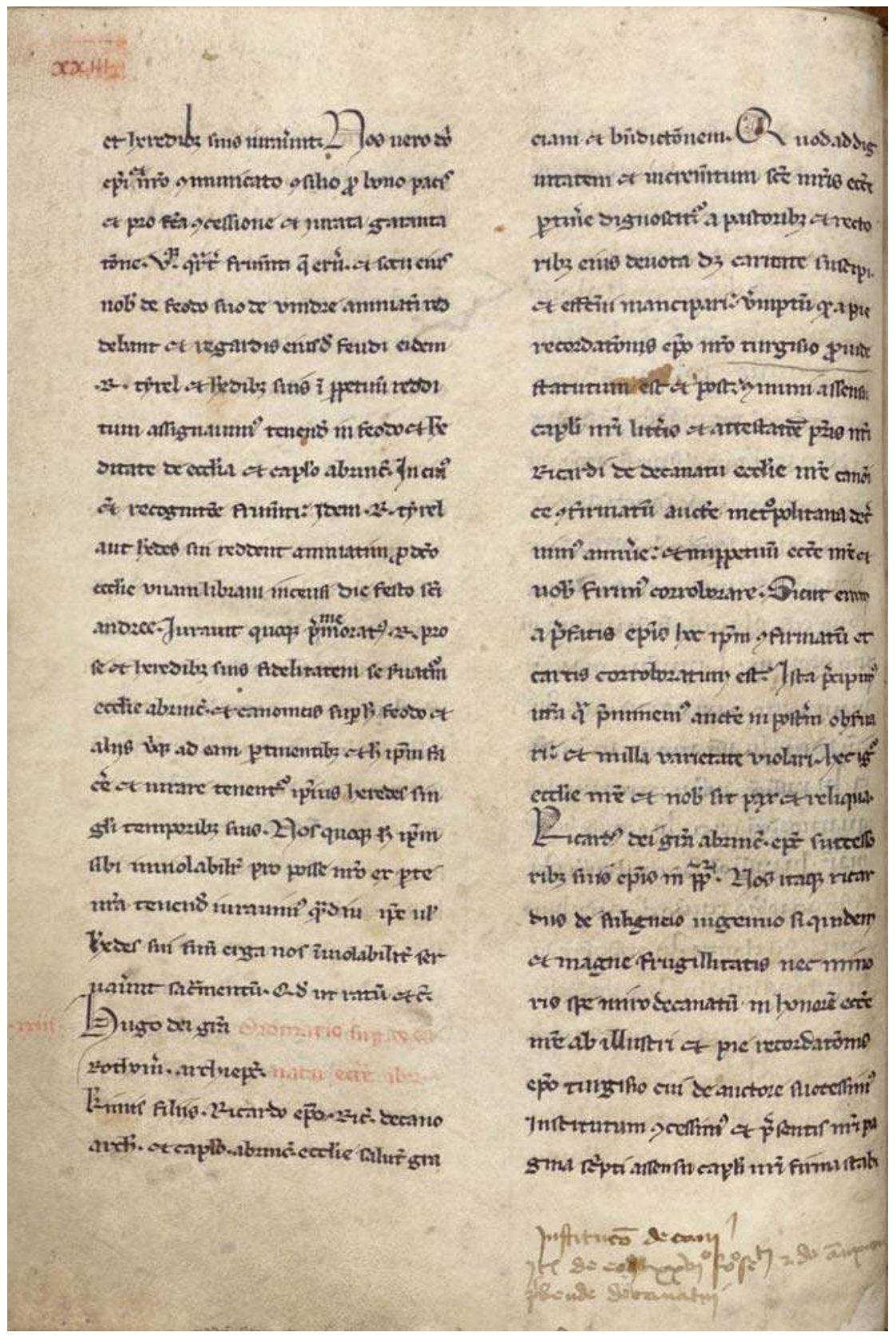

The first confirmation of Hugh of Amiens, archbishop of Rouen (Bibl. mun. d'Avranches, ms 206, fol. 8v; Ville d'Avranches) 